\title{
Catalogue of the Geological Effects of Earthquakes in Spain Based on the ESI-07 Macroseismic Scale: A New Database for Seismic Hazard Analysis
}

\author{
Pablo G. Silva ${ }^{1, * \mathbb{C}}$, Miguel A. Rodríguez-Pascua ${ }^{2}{ }^{\circledR}$, Jorge L. Giner Robles ${ }^{3}$, Javier Élez ${ }^{1}$, \\ Raúl Pérez-López ${ }^{2}$ (1) and M. Begoña Bautista Davila ${ }^{4}$ \\ 1 Depto. Geología, Escuela Politécnica Superior de Ávila, Universidad Salamanca, Ávila 05003, Spain \\ 2 Instituto Geológico y Minero de España (IGME), Madrid 28004, Spain \\ Depto. Geoquímica y Geología, Universidad Autónoma de Madrid, Madrid 28049, Spain \\ 4 Escuela Politécnica Superior de Ávila, Universidad de Salamanca, Ávila 05003, Spain \\ * Correspondence: pgsilva@usal.es
}

Received: 21 June 2019; Accepted: 24 July 2019; Published: 29 July 2019

\begin{abstract}
This paper summarizes the content and scope of the "Catalogue of Earthquake Geological Effects in Spain". The catalogue has been published by the Geological Survey of Spain (IGME) and constitutes the first official publication (in Spain) on seismic hazard containing geological information. The catalogue gathers the 51 stronger earthquakes that have occurred in Spain since the Neolithic period to the present and classifies earthquakes with geological or archaeological seismic records in paleoseismic, ancient, historical and instrumental earthquakes. The catalogue offers a variety of parametric information, quality indexes (Qe, Qi, Qg), and Environmental Seismic Intensity Scale (ESI-07) based description of environmental damage structured in individual "event files". Sixteen of the 51 catalogued events present full information files (full event files), with individualized analyses of the geological and geoarchaeological data as well as graphic information with hybrid ESI-EMS intensity maps, ShakeMaps (seismic scenarios) and complementary kmz files (Google Earth) for each of the sixteen selected earthquakes; among which is the well-known AD 1755 Lisbon earthquake-tsunami. These selected earthquakes present individual environmental earthquake effects (EEE) or earthquake archaeoseismological effects (EAE) files for each catalogued effect containing specific site geo-information and graphic data (photos, graphs, maps, etc.). The second edition of the catalogue record 1027 EEEs and 187 EAEs, of which 322 effects have individual files.
\end{abstract}

Keywords: ESI-07 scale; earthquake environmental effects (EEEs); earthquake archaeological effects (EAEs); intensity maps; seismic scenarios; earthquake catalogues; seismic hazard; Spain

\section{Introduction to the Environmental Seismic Intensity Scale ESI-07}

Recent evaluations of the geological and environmental effects of earthquakes (environmental earthquake effects (EEEs)) indicate that such effects can be certainly parameterized and used for relative intensity assessments [1,2]. The introduction of the geological analysis of earthquake effects is primarily based on the application of the Environmental Seismic Intensity Scale (ESI-07) developed by the INQUA Paleoseismology International Focus Group in 2007 [3]. The ESI-07 scale itself constitutes the quantification and parameterization of the environmental effects considered in qualitative terms by the traditional macroseismic scales, such as the Mercalli-Cancani-Sieberg (MCS), the Medvéded-Sponheuer-Karnik (MSK) or the Mercalli Modified Scale (MMS). Unfortunately, recent macroseismic practices in the European Union (European Macroseismic Sacale EMS-98) do not consider earthquake environmental or ground effects for intensity assessments [4]. In this byzantine 
situation the ESI-07 scale provides tools for intensity assessments independent from building damage and help to understand the contribution of EEEs to the global damage recorded in localities within epicentral areas $[1,5]$.

As with the traditional scales, the ESI-07 scale is a 12-degree intensity scale (Figure 1) only based on analysis and dimensions of EEEs, whose documentation has seen a considerable growth in the past decades, considering secondary (i.e., landslides, liquefaction, tsunamis, etc.) and primary (surface faulting, tectonic uplift) EEEs [3]. However, EEEs in the ESI-07 scale start to be observable, but marginal, from intensities up to IV-V; evident and noticeable from intensities VI-VII; but evident and characteristic triggering permanent changes in the geological and geomorphological record for intensities $\geq$ IX [5] (Figure 1). In this last group EEEs become dominant, characteristic and diagnostic for intensities IX-X, when commonly building damage is nearly saturated in the traditional macroseismic scales. From intensities up to $X$ building damage is saturated in most of the cases and EEEs are the unique tool for an adequate intensity assessment [1]. The ESI-07 scale aims to catalogue EEEs with a multiple purpose [5]:

- To complete historical records of earthquakes for a more fine-tuning of intensity assessments.

- To link historical EEE records with paleoseismological data in the zone/fault of interest.

- To include paleoseismological and geological earthquake records in seismic hazard assessments (SHA).

- $\quad$ To assess intensities in modern earthquakes both in urban and no-urban areas where EEEs occurred and participated in the recorded damage. This point is critical for the future refinement of the scale.

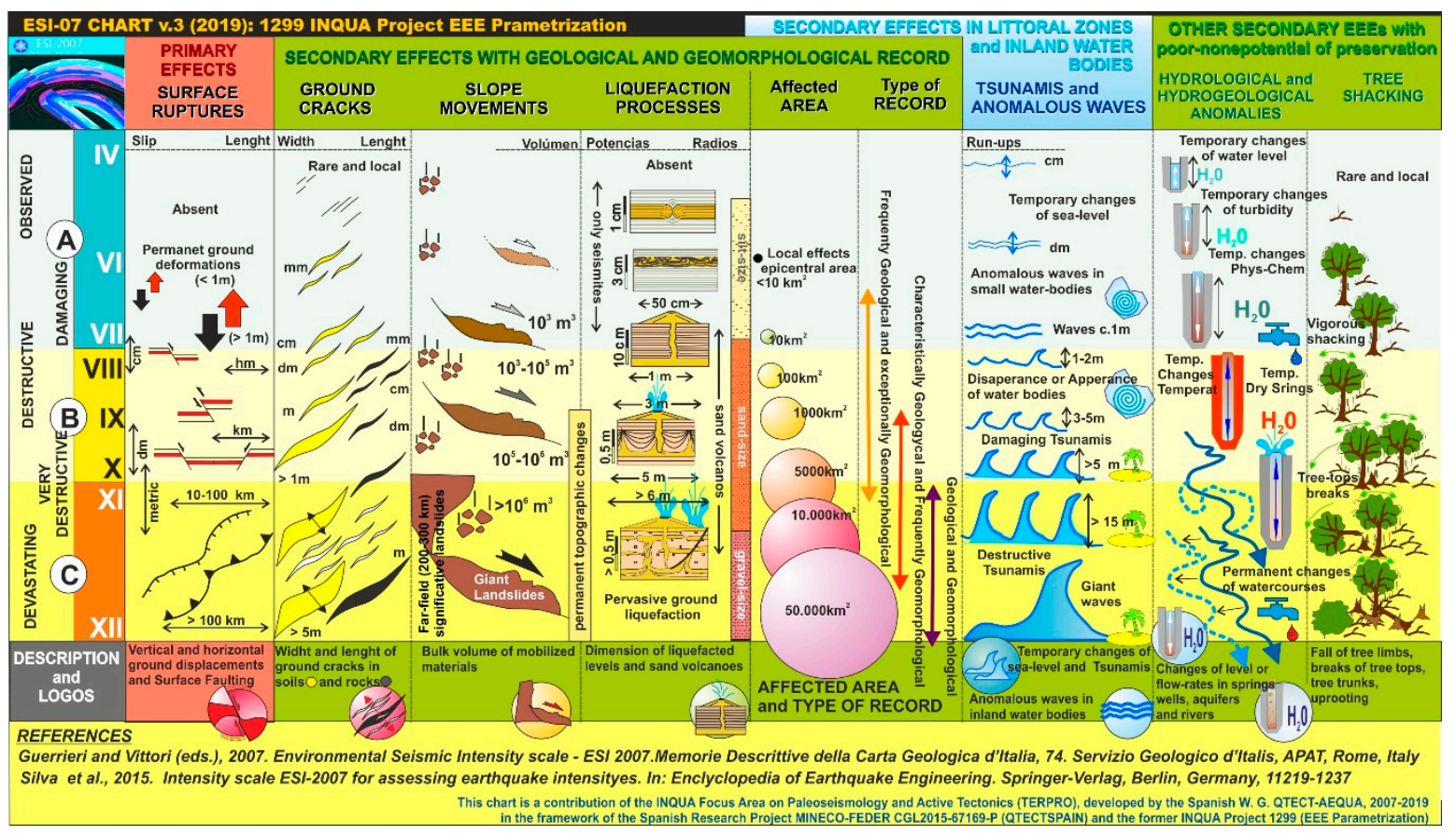

Figure 1. Synoptic chart of the Environmental Seismic Intensity Scale (ESI-07) scale illustrating the earthquake environmental effects modified and updated from Silva et al. [5].

In summary, analyses of EEEs try to enlarge the temporal period of macroseismic observations and data some thousand years ago to the more recent geological past, commonly to the last 10,000-12,000 years BP (i.e., Holocene epoch) [1,5,6]. This fact is essential to perform the scientific analysis of a particular geological process (Seismic Cycle) which normally exceeds the temporal scales commonly considered in the conventional seismic catalogues [5]. In the case of Spain, the official catalogue of historical earthquakes extends to the year 800 BCE [7]. However, as noticed in recent 
macroseismic reviews, the historical data are scarce and doubtful before the year $1000 \mathrm{CE}$, and nearly accurate for strong events from the 14th-15th centuries [8-10]. This implies about 500-600 years of useful macroseismic record for Spain, which in turn are the approximate return periods used in SHA for seismic codes [11,12].

\section{The Content of the Catalogue}

The catalogue includes data for the 51 strongest earthquakes felt in the Iberian Peninsula from the Neolithic period to the present (Figure 2). The reviewed earthquake list also incorporates the well-known AD 1755 Lisbon earthquake-tsunami with 753 catalogued EEEs including the far-field natural anomalies recorded in the British Islands, Central-Northern Europe, Africa and The Caribbean Sea. The catalogue also considers geological information for ancient earthquakes only documented in archaeological sites, differentiating several types of earthquake archeological effects (EAEs) of the classification [13]. Among the most ancient events included in the catalogue are those of the Cueva del Toro in Antequera (Málaga) of Neolithic age (c. 3700 BCE) [14] and the Bronze Age event of La Tira del Lienzo in Totana, Murcia (c. 1550 BCE) [15]. A surface rupture affecting dry masonry walls along the well-known Lorca-Alhama de Murcia left-lateral fault in the Eastern Betic Cordillera documents this Bronze Age earthquake. This fault is also responsible for the last damaging earthquake that occurred in Spain, the 2011 CE Lorca event $(5.1 \mathrm{Mw}$ ) which produced about 250 EEEs (mainly slope movements) with a maximum intensity of VIII ESI-07 [16] of which the more relevant 49 EEEs have been catalogued [10]. The macroseismic area of this instrumental earthquake was located few kilometers north of Lorca in a nearly depopulated area without EMS assessments, but in which important collapses of the subvertical slopes of dry creeks massively occurred coinciding with the area where the earthquake epicenter was located [10]. This fact illustrates the value of the ESI-07 scale even for instrumental events, since this area of massive slope collapses identified an ESI intensity VIII, whilst the EMS assessments only quoted a maximum intensity of VII EMS in the locality of Lorca [16]. Figure 2 illustrates the distribution of the 51 catalogued events around the Iberian Peninsula identifying the Betic Cordillera (southeast) and the Pyrenees (north) as the two main zones where the convergence between the two large tectonic plates of Eurasia and Africa trigger the ongoing seismotectonic activity. A third important zone is the Gulf of Cádiz and the southern Portugal offshore area, "locus" of nucleation of strong historical earthquake-tsunami events in response to the suspected lithospheric delamination of the Atlantic oceanic floor beneath the Iberian Peninsula (Figure 2) [17,18].

The newly edited catalogue is an official publication of the Geological Survey of Spain (IGME) and does not aim to substitute the running seismological catalogues based on historical data written in EMS language [7]. Furthermore, the published ESI-07 Catalogue [10] incorporates all the available EMS macroseismic data to produce hybrid ESI-EMS Intensity maps as suggested in the guidelines of the ESI-07 scale [3]. Therefore, the variety of geological, geoarchaeological, archaeological and historic information summarized in the catalogue aims to complement the existing EMS seismic catalogues to improve (or refine) seismic scenarios for historical and instrumental earthquakes for their further application to SHA studies [19] and to earthquake drills [20]. The compilation of the information started in the year 2008 [12] leading to the first edition of the catalogue in 2014 [20] and this second edition (revised and expanded) in the present year [9], resulting in the most complete edition of a catalogue on geological effects of the earthquakes at national scale [10]. The next sections explain the content, structure and the variety of graphical information included in the Spanish EEEs catalogue. 
Table 1. Parametric list of pre-instrumental (1900-1963) and instrumental earthquakes (after 1963) included in the Spanish catalogue [10] with their corresponding "Quality indexes" discussed in text. Earthquakes in bold corresponds to those with "full event files"; the remainder events have only summarized information in "event files". Two earthquakes are still under study. See Figure 2 for earthquake location.

\begin{tabular}{|c|c|c|c|c|c|c|c|c|c|}
\hline Year (CE) & $\begin{array}{c}\text { Month \& } \\
\text { Day }\end{array}$ & Longitude & Latitude & $\begin{array}{l}\text { Quality } \\
\text { Qe Qi Qg }\end{array}$ & Magnitude & EMS-98 & ESI-07 & Location & Code Number \\
\hline 1911 & Mar 21 & $1^{\circ} 15^{\prime} \mathrm{O}$ & $38^{\circ} 01^{\prime} \mathrm{N}$ & AIC & $5.7 \mathrm{Ms}$ & VII-VIII & & Torres de Cotilla. Murcia & 43. PRE 19110321 \\
\hline 1911 & Apr 03 & $1^{\circ} 12^{\prime} \mathrm{O}$ & $38^{\circ} 06^{\prime} \mathrm{N}$ & AIC & $5.3 \mathrm{Ms}$ & VIII & VIII & Lorquí. Murcia & 44. PRE 19110403 \\
\hline 1911 & May 31 & $3^{\circ} 42^{\prime} \mathrm{O}$ & $37^{\circ} 12^{\prime} \mathrm{N}$ & AIC & 4.9 Ms & VII-VIII & VIII & Santa Fe. Granada & 45. PRE 19119531 \\
\hline 1917 & Jan 28 & $1^{\circ} 21^{\prime} \mathrm{O}$ & $38^{\circ} 01^{\prime} \mathrm{N}$ & AIC & & VI-VII & & Torres de Cotilla. Murcia & 46. PRE 19170128 \\
\hline 1919 & Sep 10 & $0^{\circ} 50^{\prime} \mathrm{O}$ & $38^{\circ} 05^{\prime} \mathrm{N}$ & AIB & $5.2 \mathrm{Ms}$ & VIII & VIII & Jacarilla. Alicante & 47. PRE 19191010 \\
\hline 1930 & Jul 05 & $4^{\circ} 38^{\prime} \mathrm{O}$ & $37^{\circ} 35^{\prime} \mathrm{N}$ & AIB & $5.4 \mathrm{Ms}$ & VII-VIII & & Montilla. Cordoba & 48. Under study \\
\hline 1956 & Apr 19 & $3^{\circ} 41^{\prime} \mathrm{O}$ & $37^{\circ} 11^{\prime} \mathrm{N}$ & IIB & $5.0 \mathrm{Ms}$ & VIII & VIII & Albolote. Granada & 49. PRE 19560419 \\
\hline 1964 & Jun 09 & $2^{\circ} 34^{\prime} \mathrm{O}$ & $37^{\circ} 44^{\prime} \mathrm{N}$ & IIB & $4.8 \mathrm{mb}$ & VIII & VIII & Galera. Granada & 50. PRE 19640609 \\
\hline 1993 & Dec 23 & $2^{\circ} 55^{\prime} \mathrm{O}$ & $36^{\circ} 46^{\prime} \mathrm{N}$ & III & $5.0 \mathrm{Mw}$ & VII & & Adra. Almería & 51. Under study \\
\hline 1999 & Feb 2 & $1^{\circ} 50^{\prime} \mathrm{O}$ & $38^{\circ} 10^{\prime} \mathrm{N}$ & III & $4.8 \mathrm{Mw}$ & VII & VII & Mula. Murcia & 52. INS 19990202 \\
\hline 2002 & Aug 6 & $1^{\circ} 51^{\prime} \mathrm{O}$ & $37^{\circ} 53^{\prime} \mathrm{N}$ & III & $5.0 \mathrm{Mw}$ & VI & VI & Bullas. Murcia & 53. INS 20020806 \\
\hline 2003 & May 21 & $3^{\circ} 42^{\prime} \mathrm{O}$ & $36^{\circ} 541^{\prime} \mathrm{N}$ & III & $6.8 \mathrm{Mw}$ & I & $\mathrm{VI}^{*}$ & $\begin{array}{l}\text { Mahón (tsunami*) Balearic } \\
\text { Islandas }\end{array}$ & 54. INS 20030521 \\
\hline 2005 & Jan 29 & $1^{\circ} 45^{\prime} \mathrm{O}$ & $37^{\circ} 51^{\prime} \mathrm{N}$ & III & $4.8 \mathrm{Mw}$ & VII & VII & La Paca. Murcia & 55. INS 20050129 \\
\hline 2011 & May 11 & $1^{\circ} 42^{\prime} \mathrm{O}$ & $37^{\circ} 43^{\prime} \mathrm{N}$ & III & $5.2 \mathrm{Mw}$ & VII & VIII & Lorca. Murcia & 56. INS 20110511 \\
\hline
\end{tabular}

Table 2. Parametric list of historical, ancient and paleoseismic events included in the catalogue with their corresponding "Quality indexes" discussed in text. Earthquakes in bold corresponds to those with "full event files"; the remainder events have only summarized information in "Event files". Two historical earthquakes are still under study. See Figure 2 for earthquake location.

\begin{tabular}{|c|c|c|c|c|c|c|c|c|c|}
\hline Year (CE) & $\begin{array}{c}\text { Month \& } \\
\text { Day }\end{array}$ & Longitude & Latitude & $\begin{array}{c}\text { Quality Qe } \\
\text { Qi Qg }\end{array}$ & Magnitude & EMS-98 & ESI-07 & Location & Code Number \\
\hline $\begin{array}{c}4200-3700 \\
\text { BCE }\end{array}$ & & $4^{\circ} 32^{\prime} \mathrm{O}$ & $36^{\circ} 57^{\prime} \mathrm{N}$ & CCG & $\geq 6.7 \mathrm{Mw}$ & & $\geq \mathrm{IX}$ & Cueva del Toro. Antequera. Málaga & 1. APQ 004AC3700 \\
\hline $\begin{array}{c}1900-1550 \\
\text { BCE }\end{array}$ & & $1^{\circ} 29^{\prime} \mathrm{O}$ & $37^{\circ} 47^{\prime} \mathrm{N}$ & GGG & $6.4 \mathrm{Mw}$ & $\geq \mathrm{VIII}$ & $\geq \mathrm{VIII}$ & Tira del Lienzo. Totana, Murcia & 2. APQ 002AC1550 \\
\hline $800 \mathrm{BCE}$ & & $2^{\circ} 46^{\prime} \mathrm{E}$ & $42^{\circ} 20^{\prime} \mathrm{N}$ & $\mathrm{CCC}$ & & & $\geq \mathrm{VIII}$ & Pirineos Orientales Alto Ampurdán. Gerona & 3. HST 001AC800 \\
\hline 575-500 BCE & & $2^{\circ} 46^{\prime} \mathrm{E}$ & $42^{\circ} 20^{\prime} \mathrm{N}$ & $\mathrm{CCC}$ & & & $\geq \mathrm{VIII}$ & Pirineos Orientales Alto Ampurdán. Gerona & 4. HST 001AC 575 \\
\hline 570-500 BCE & & $10^{\circ} 00^{\prime} \mathrm{O}$ & $36^{\circ} 28^{\prime} \mathrm{N}$ & $\mathrm{CCC}$ & & & $\geq \mathrm{VIII}$ & Andalucía, Mar Alborán. Mediterranean & 5. HST 001AC500 \\
\hline 218-209 BCE & & $9^{\circ} 42^{\prime} \mathrm{O}$ & $36^{\circ} 38^{\prime} \mathrm{N}$ & GGG & $\geq 8.0 \mathrm{Mw}$ & & $\geq \mathrm{IX}$ & Lacus Ligustinus: SW Cabo San Vicente, Atlantic Ocean & 6. GEO 001AC218 \\
\hline $040-060$ CE & & $5^{\circ} 46^{\prime} \mathrm{O}$ & $36^{\circ} 05^{\prime} \mathrm{N}$ & QQG & $\geq 5.5 \mathrm{Mw}$ & $\geq$ VIII & $\geq \mathrm{VIII}$ & Baelo Claudia. Bolonia. Cádiz & 7. ARQ 004060 \\
\hline $260-280 \mathrm{CE}$ & & $5^{\circ} 46^{\prime} \mathrm{O}$ & $36^{\circ} 05^{\prime} \mathrm{N}$ & QQG & $\geq 5.5 \mathrm{Mw}$ & Z VIII & $\geq \mathrm{VIII}$ & Baelo Claudia. Bolonia. Cádiz & 8. ARQ 0260280 \\
\hline
\end{tabular}


Table 2. Cont

\begin{tabular}{|c|c|c|c|c|c|c|c|c|c|}
\hline Year (CE) & $\begin{array}{c}\text { Month \& } \\
\text { Day }\end{array}$ & Longitude & Latitude & $\begin{array}{l}\text { Quality Qe } \\
\text { Qi Qg }\end{array}$ & Magnitude & EMS-98 & ESI-07 & Location & Code Number \\
\hline $300-400 \mathrm{CE}$ & & $1^{\circ} 39^{\prime} \mathrm{O}$ & $38^{\circ} 35^{\prime} \mathrm{N}$ & GGG & $6.8 \mathrm{Mw}$ & & $\mathrm{x}$ & Illunum Tobarra. Albacete & 9. GEO 0300400 \\
\hline $350-400 \mathrm{CE}$ & & $3^{\circ} 19^{\prime} \mathrm{O}$ & $40^{\circ} 30^{\prime} \mathrm{N}$ & QQG & $\geq 5.5 \mathrm{Mw}$ & $\geq \mathrm{VIII}$ & $\geq \mathrm{VIII}$ & Complutum, Alcalá de Henares, Madrid & 10. ARQ 0350400 \\
\hline $881 \mathrm{CE}$ & May 26 & $8^{\circ} 00^{\prime} \mathrm{O}$ & $36^{\circ} 00^{\prime} \mathrm{N}$ & DCC & $7.2 \mathrm{Mw}$ & $\mathrm{XI}-\mathrm{X}$ & XI & Golfo de Cádiz. Atlantic Ocean & 11. HST 08810000 \\
\hline $949 \mathrm{CE}$ & & & & DCC & & & & Zamora-Oporto. Atlantic Ocean & 12. HST 09490000 \\
\hline $1048 \mathrm{CE}$ & & $0^{\circ} 55^{\prime} \mathrm{O}$ & $38^{\circ} 05^{\prime} \mathrm{N}$ & DCQ & & VIII & VIII & Orihuela. Alicante & 13. HST 10480000 \\
\hline $1169 \mathrm{CE}$ & Jan 21 & $4^{\circ} 00^{\prime} \mathrm{O}$ & $38^{\circ} 00^{\prime} \mathrm{N}$ & DCQ & $6.0 \mathrm{Mw}$ & VIII-IX & IX & Andújar. Jaén & 14. HST 11690121 \\
\hline $1356 \mathrm{CE}$ & Agu 24 & $10^{\circ} 00^{\prime} \mathrm{O}$ & $36^{\circ} 30^{\prime} \mathrm{N}$ & DCC & $6.5 \mathrm{Mw}$ & VIII & & SW. Cabo San Vicente. Atlantic Ocean & 15. HST 13560824 \\
\hline $1373 \mathrm{CE}$ & Mar 02 & $0^{\circ} 45^{\prime} \mathrm{O}$ & $42^{\circ} 30^{\prime} \mathrm{N}$ & CCG & $6.2 \mathrm{Mw}$ & VIII-IX & IX & Ribagorça, Lerida & 16. HST 13730302 \\
\hline $1396 \mathrm{CE}$ & Dec 18 & $0^{\circ} 13^{\prime} \mathrm{O}$ & $39^{\circ} 05^{\prime} \mathrm{N}$ & BBB & $6.5 \mathrm{Mw}$ & VIII-IX & $x$ & Tavernes de Valldigna. Valencia & 17. HST 13961218 \\
\hline $1427 \mathrm{CE}$ & May 15 & $2^{\circ} 30^{\prime} \mathrm{E}$ & $42^{\circ} 12^{\prime} \mathrm{N}$ & BBG & & VIII-IX & IX-X & Olot. Gerona & 18. Under study \\
\hline $1428 \mathrm{CE}$ & Feb 02 & $2^{\circ} 10^{\prime} \mathrm{E}$ & $42^{\circ} 21^{\prime} \mathrm{N}$ & BBG & & IX-X & IX-X & Queralbs. Gerona & 19. Under study \\
\hline $1431 \mathrm{CE}$ & Apr 24 & $3^{\circ} 38^{\prime} \mathrm{O}$ & $37^{\circ} 08^{\prime} \mathrm{N}$ & СBB & $6.7 \mathrm{Mw}$ & VIII-IX & $\geq \mathrm{VIII}$ & Sierra Elvira. Granada & 20. HST 14310424 \\
\hline $1494 \mathrm{CE}$ & Jan 26 & $4^{\circ} 20^{\prime} \mathrm{O}$ & $36^{\circ} 35^{\prime} \mathrm{N}$ & CBB & & VIII & VIII & Málaga. Málaga & 21. HST 14940126 \\
\hline $1504 \mathrm{CE}$ & Apr 05 & $5^{\circ} 28^{\prime} \mathrm{O}$ & $37^{\circ} 23^{\prime} \mathrm{N}$ & BAA & $6.8 \mathrm{Mw}$ & VIII-IX & IX & Carmona. Sevilla & 22. HST 15040405 \\
\hline $1518 \mathrm{CE}$ & Nov 09 & $1^{\circ} 52^{\prime} \mathrm{O}$ & $37^{\circ} 14^{\prime} \mathrm{N}$ & BBA & & VIII-IX & IX & Vera. Almaría & 23. HST 15181109 \\
\hline $1522 \mathrm{CE}$ & Sep 22 & $2^{\circ} 40^{\prime} \mathrm{O}$ & $36^{\circ} 58^{\prime} \mathrm{N}$ & DBB & $6.5 \mathrm{Mw}$ & VIII-IX & IX & W. Alhama de Almería. Almería & 24. HST 15220922 \\
\hline $1531 \mathrm{CE}$ & Sep 30 & $2^{\circ} 44^{\prime} \mathrm{O}$ & $37^{\circ} 32^{\prime} \mathrm{N}$ & СBВ & & VIII-IX & IX & Baza. Granada & 25. HST 15310930 \\
\hline $1620 \mathrm{CE}$ & Dec 02 & $0^{\circ} 28^{\prime} \mathrm{O}$ & $38^{\circ} 42^{\prime} \mathrm{N}$ & СBB & & VII-VIII & VIII & Alcoy. Alicante & 26. HST 16201202 \\
\hline $1656 \mathrm{CE}$ & Jun 07 & $1^{\circ} 14^{\prime} \mathrm{O}$ & $40^{\circ} 05^{\prime} \mathrm{N}$ & BBB & & VIII & VIII & Ademuz. Valencia & 27. HST 16560607 \\
\hline $1644 \mathrm{CE}$ & Jun 19 & $0^{\circ} 25^{\prime} \mathrm{O}$ & $38^{\circ} 48^{\prime} \mathrm{N}$ & CBB & & VIII & & Muro de Alcoy. Alicante & 28. HST 16440619 \\
\hline $1658 \mathrm{CE}$ & $\operatorname{Dec} 31$ & $2^{\circ} 28^{\prime} \mathrm{O}$ & $36^{\circ} 50^{\prime} \mathrm{N}$ & DBC & & VIII & $\mathrm{x}$ & Almería. Almería & 29. HST 16581231 \\
\hline $1674 \mathrm{CE}$ & Agu 28 & $1^{\circ} 42^{\prime} \mathrm{O}$ & $37^{\circ} 41^{\prime} \mathrm{N}$ & BBB & & VIII & & Lorca. Murcia & 30. HST 16740828 \\
\hline $1680 \mathrm{CE}$ & Oct 9 & $4^{\circ} 36^{\prime} \mathrm{O}$ & $36^{\circ} 48^{\prime} \mathrm{N}$ & BAB & $6.8 \mathrm{Mw}$ & VIII-IX & IX & NW de Málaga. Málaga & 31. HST 16801009 \\
\hline $1722 \mathrm{CE}$ & Dec 27 & $7^{\circ} 46^{\prime} \mathrm{O}$ & $36^{\circ} 24^{\prime} \mathrm{N}$ & $\mathrm{CBC}$ & $6.5 \mathrm{Mw}$ & VIII & & Golfo de Cádiz. Atlantic Ocean & 32. Under study \\
\hline $1748 \mathrm{CE}$ & Mar 23 & $0^{\circ} 38 \mathrm{O}$ & $39^{\circ} 02^{\prime} \mathrm{N}$ & AAA & $6.2 \mathrm{Mw}$ & IX & IX & Estubeny. Valencia & 33. HST 17480323 \\
\hline $1755 \mathrm{CE}$ & Nov 01 & $10^{\circ} 00^{\prime} \mathrm{O}$ & $36^{\circ} 30^{\prime} \mathrm{N}$ & DAA & $8.5 \mathrm{Mw}$ & XI-XII & XI & Lisbon Event: SW Cabo San Vicente. Atlantic Oc. & 34. HST 17551101 \\
\hline $1804 \mathrm{CE}$ & Jan 13 & $3^{\circ} 35^{\prime} \mathrm{O}$ & $36^{\circ} 05^{\prime} \mathrm{N}$ & $\mathrm{CAB}$ & $6.7 \mathrm{Mw}$ & VII-VIII & VIII & Almería, Mar Alborán Mediterranean & 35. HST 18040113 \\
\hline $1804 \mathrm{CE}$ & Agu 25 & $2^{\circ} 50^{\prime} \mathrm{O}$ & $36^{\circ} 46^{\prime} \mathrm{N}$ & BAB & $6.4 \mathrm{Mw}$ & VIII-IX & IX & Dalías. Almería & 36. HST 18040825 \\
\hline $1806 \mathrm{CE}$ & Oct 27 & $3^{\circ} 44^{\prime} \mathrm{O}$ & $37^{\circ} 14^{\prime} \mathrm{N}$ & $\mathrm{ABB}$ & $5.3 \mathrm{M}$ & VIII & & Pinos-Puente. Granada & 37. HST 18061027 \\
\hline $1829 \mathrm{CE}$ & Mar 21 & $0^{\circ} 41^{\prime} \mathrm{O}$ & $38^{\circ} 05^{\prime} \mathrm{N}$ & AAA & $6.6-6.9 \mathrm{Mw}$ & IX-X & $\mathrm{x}$ & Torrevieja. Alicante & 38. HST 18290321 \\
\hline $1845 \mathrm{CE}$ & Oct 07 & $0^{\circ} 45^{\prime} \mathrm{E}$ & $41^{\circ} 02^{\prime} \mathrm{N}$ & BBA & $5.1 \mathrm{Mw}$ & VI-VII & VII & Tivissa. Tarragona & 39. HST 18451007 \\
\hline $1851 \mathrm{CE}$ & May 15 & $2^{\circ} 40^{\prime} \mathrm{E}$ & $39^{\circ} 38^{\prime} \mathrm{N}$ & BAA & $\geq 4.5 \mathrm{Mw}$ & VII & VII & NE Palma de Mallorca. Balearic Islands & 40. HST 18510515 \\
\hline $1863 \mathrm{CE}$ & Jun 10 & $1^{\circ} 56^{\prime} \mathrm{O}$ & $37^{\circ} 22^{\prime} \mathrm{N}$ & AAA & $4.2-4.6 \mathrm{Mw}$ & VI-VII & VIII & Huércal-Overa. Almería & 41. HST 18630610 \\
\hline $1884 \mathrm{CE}$ & Dec 25 & $3^{\circ} 59^{\prime} \mathrm{O}$ & $37^{\circ} 00^{\prime} \mathrm{N}$ & AAA & $6.5-6.7 \mathrm{Mw}$ & IX-X & $x$ & Arenas del Rey. Granda & 42. HST 18841225 \\
\hline
\end{tabular}




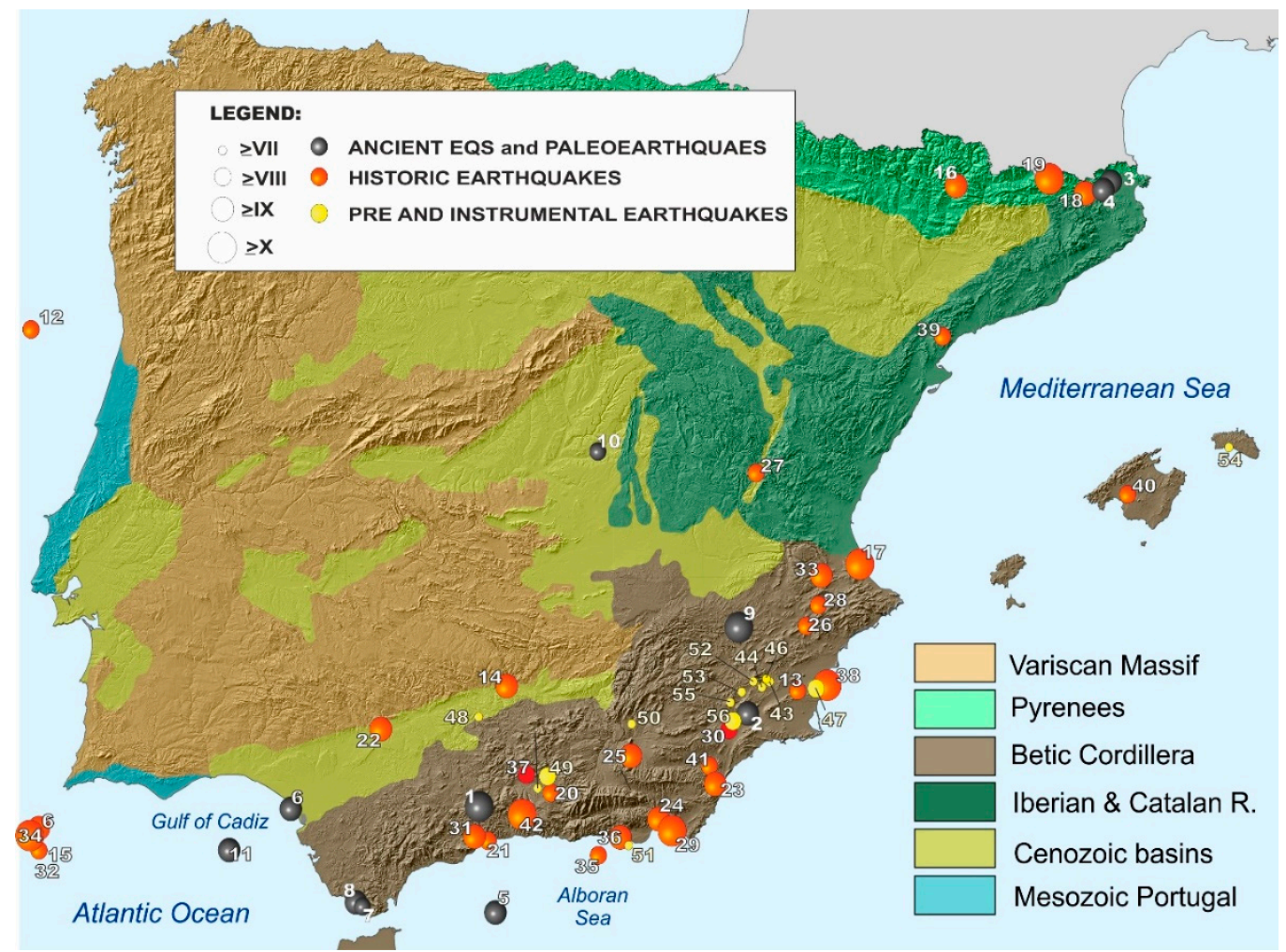

Figure 2. Geological Sketch of the Iberian Peninsula displaying the location of the 56 earthquakes listed in Tables 1 and 2 (51 of them catalogued). For earthquake identification, please see numbered lists of Tables 1 and 2.

\section{Type of Catalogued Earthquakes}

Conventional seismic catalogues include information for historical and instrumental earthquakes, the last commonly available from the first quarter of the 20th century for most of the European countries. In contrast, the Spanish catalogue differentiates five types (or periods) of seismic events for which the seismic information comes from different sources, with a variety of geological, archaeological or geoarchaeological data. Figure 3 illustrates the provenance and use of the different typology of macroseismic information used for the elaboration of the ESI-07 catalogue [10]. The different types of events are the following:

(a) Instrumental Earthquakes (Code: INS) occurred since AD 1963 to the present and recorded by the National Seismic Network of the "Instituto Geográfico Nacional" (IGN). These types of events have the more precise instrumental records, mainly from 1988 CE [21], complemented with quality macroseismic information. In some cases, there are specific field reports produced by official institutions (i.e., IGN, IGME and IAG) or Civil Protection for those that occurred from 1995 CE. Five events of this type have been catalogued, one of them with complete information (Table 1) which corresponds to the Lorca 2011 CE earthquake-the only one with a specific geological field report produced by the Geological Survey of Spain [22].

(b) Pre-Instrumental Earthquakes (Code: PRE) occurred between the years AD 1900 and 1962. This is a special period in Spain between the installation of the first mechanical seismographs and the implementation of the National Seismic Network ("Red Sísmica Nacional") [21]. These types of events have macroseismic information of different quality from old seismic records and field reports. In general, most of this type of events are the worst documented ones from the point of view of the geological effects. The catalogue includes seven (7) events of this type, two of them with complete macroseismic information (Table 1). 
(c) Historical Earthquakes (Code: HST) are documented by written historical sources from the year 800 BCE to 1900 CE. For this type of events the information is of macroseismic character but strongly supported by the analysis of the geological effects (EEEs) reported in historic documents and newly studied archaeoseismological data (EAEs), especially for those occurred after the 1755 CE Lisbon Earthquake-Tsunami for which field earthquake reports are common. Forty-one events of this type have been catalogued, nine of them with complete macroseismic information (Table 2).

(d) Ancient Earthquakes (Code: ARQ). Mainly documented by archaeological and geoarchaeological data (EAEs) and supported by a variety of geological data (EEEs), but still not included in the conventional EMS catalogues [7] or in the updated on-line databases of the National Seismic Network [23]. As aforementioned, within this category the more ancient ones are the Neolithic event documented in "La Cueva del Toro" in Antequera (Málaga) and the Bronze Age event of "La Tira del Lienzo" (Murcia) located just above the trace of the Lorca-Alhama de Murcia fault. However, the more significant events included in this category are those that occurred during the Roman Period in Spain documented in the archaeological sites of "Baelo Claudia" [24] in Tarifa (Cádiz) and "Complutum" [25] in Alcalá de Henares, $25 \mathrm{~km}$ south of the city of Madrid. There are five (5) events catalogued for this category, three of them with complete macroseismic information (Table 2).

(e) Paleoearthquakes or paleoseismic events (Code: GEO) with only geological record, albeit in some cases supported by limited geoarchaeological data. This type of event covers from the most ancient historical periods in Spain (c. 10th century CE) to the onset of the Holocene epoch (c. $11.2 \mathrm{ka}$ $\mathrm{BP}$ ) and they are not included in the conventional seismic catalogues as commonly occurs with the ancient earthquakes. These events are documented in scientific papers published during the 21st century, and they correspond to fault-trenching analyses (primary surface ruptures) or EEEs analysis (primary and secondary effects). Those related to fault-trenching studies correspond to surface-faulting events $(\geq 7.0 \mathrm{Mw})$ that occurred during the late Holocene. However, there are fault-trenching data for some ancient earthquakes such as the Tobarra (Albacete) that occurred around the 500 CE [26] or Historical events such as the Arenas del Rey (Granada) that occurred in 1884 CE [27]. Another case of paleoearthquake largely documented by secondary EEEs is the 218 BCE Lacus Ligustinus event recorded in the present "Doñana Marshlands" (an ancient lake by that time) at the Guadalquivir river outlet in the Gulf of Cádiz (Atlantic Ocean) [28]. These authors identify an earthquake-tsunami event similar to the $1755 \mathrm{CE}$ Lisbon event flooding the ancient roman embayment and breaking the existing littoral spit-bars. Other authors document this event in turbidite layers obtained in deep sea cores in the Atlantic ocean near the Gorringe Bank [29] or in other marshlands of the Gulf of Cádiz, such as the Odiel and Tinto river mouths at Huelva or the Guadalete river mouth near Cádiz [30,31]. It is to note that the Lacus Ligustinus event is the unique geological event with historical written records describing the destruction of Cádiz just before the march of Hannibal to Rome across the Alps in the beginning of the Second Punic War in 218 BCE [32]. All these paleoseismic events are supported by a significant number of geochronologic data $\left({ }^{14} \mathrm{C}, \mathrm{OSL}\right.$ and TL data), as is also the case for most of the ancient earthquakes further documented by archaeological data. 


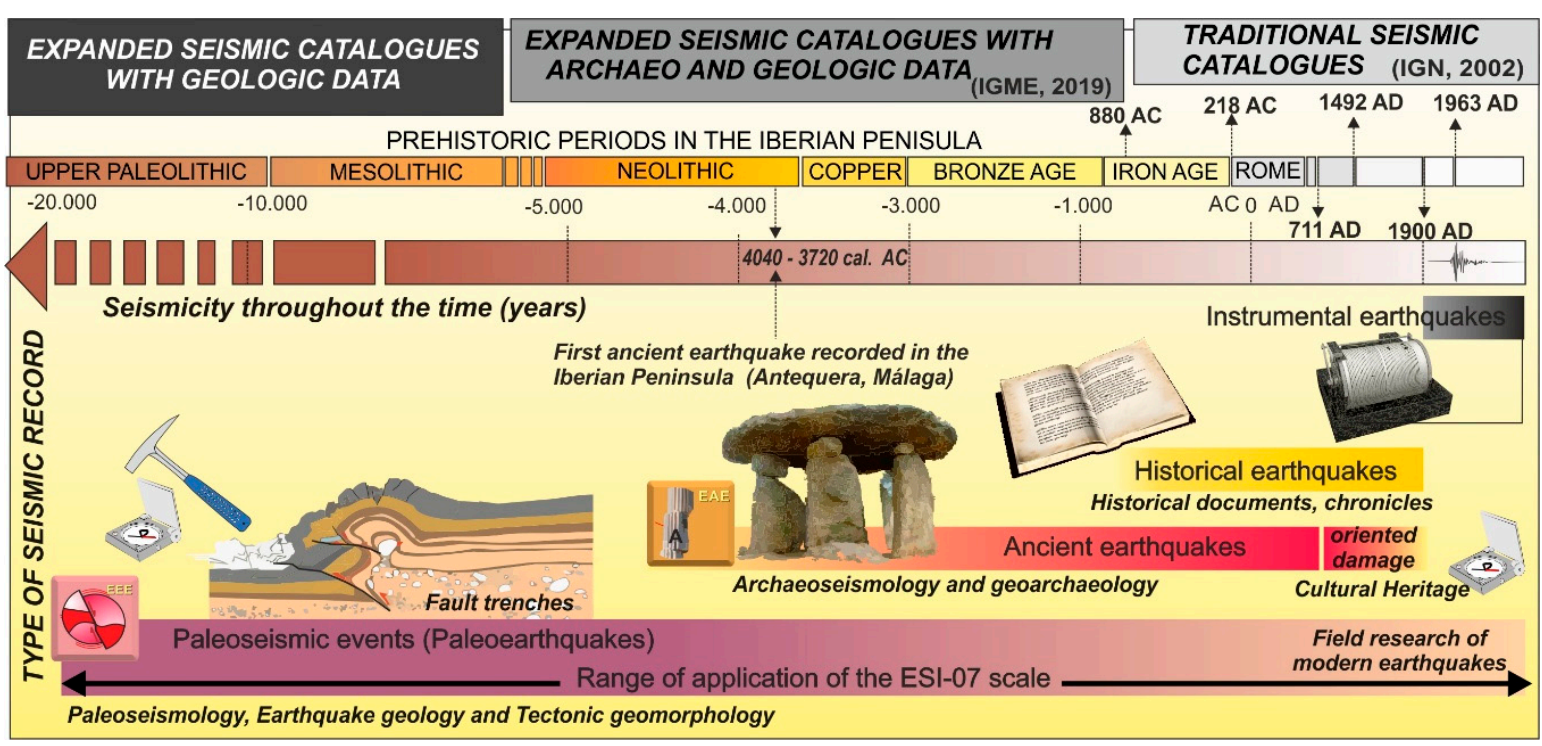

Figure 3. Type of information and temporal extent of the different types of earthquakes (paleo, ancient, historical, pre-instrumental and instrumental) in relation to the time-record for the different prehistoric and historic periods in the Iberian Peninsula. The temporal scale highlights representative historic cut-off dates for the type of information of the catalogued events.

\section{Type of Information for the Catalogued Earthquakes.}

The written documentary information is unequal for the different historical periods of Spain [8]. The conventional seismic catalogues only include eighteen (18) earthquakes previous to the sixth century CE, most of them suspected strong events that occurred in the Gulf of Cádiz, the Atlantic Portuguese coast or the Pyrenees [7]. The oldest ones (years 800 to 500 BCE) correspond to suspected events that occurred near the first settlements of the Phoenicians in the Pyrenees (Emporiom, Gerona) or in the Gibraltar Strait (Gadir, Cádiz). However, most of these old historic earthquakes correspond to those that occurred during the Roman period (third century BCE to fifth century $\mathrm{CE}$ ) in the southern zone of the Iberian Peninsula. More consistent historical data appear from 800 CE by Muslim historians [5], but is not until the Reconquest of the Iberian Peninsula by the Catholic Kings in the $1492 \mathrm{CE}$, when earthquake data start to be really of quality and representative. Fifty-eight earthquakes are catalogued before this date, half of them (29) for the period between the 11th and 16th centuries CE [10]. The number of historical events catalogued between 1500 and 1800 CE is around 500 which contrast with the about 1200 ones catalogued for the 19th century alone [19]. These numbers help to illustrate the unequal written historical information for seismic events in Spain, even though a majority of the strong earthquakes ( $\geq$ VIII EMS) occurred after the 10th century can be considered catalogued. This situation is not the same for those historic events that occurred before the 10th century, when the near absence of written seismic information is noticeable including the roman and visigothic periods (218 BCE-711 CE). The low quality of historical data for these period implied that most of these historical earthquakes were removed from the official seismic database of the IGN [23]. After the critical review of Udías [5], only 32 earthquakes remain catalogued before $1500 \mathrm{CE}$, all them within the present Common Era (CE), and 23 of them occurred in the period 1000-1500 CE (Figure 4). This seismic account contrasts with the about 480 events catalogued for the period 1500-1800 CE and the near 1200 earthquakes catalogued for the 19th century (excluding foreshocks and aftershocks events) still remaining in the official seismic databases (Figure 4) [23]. 


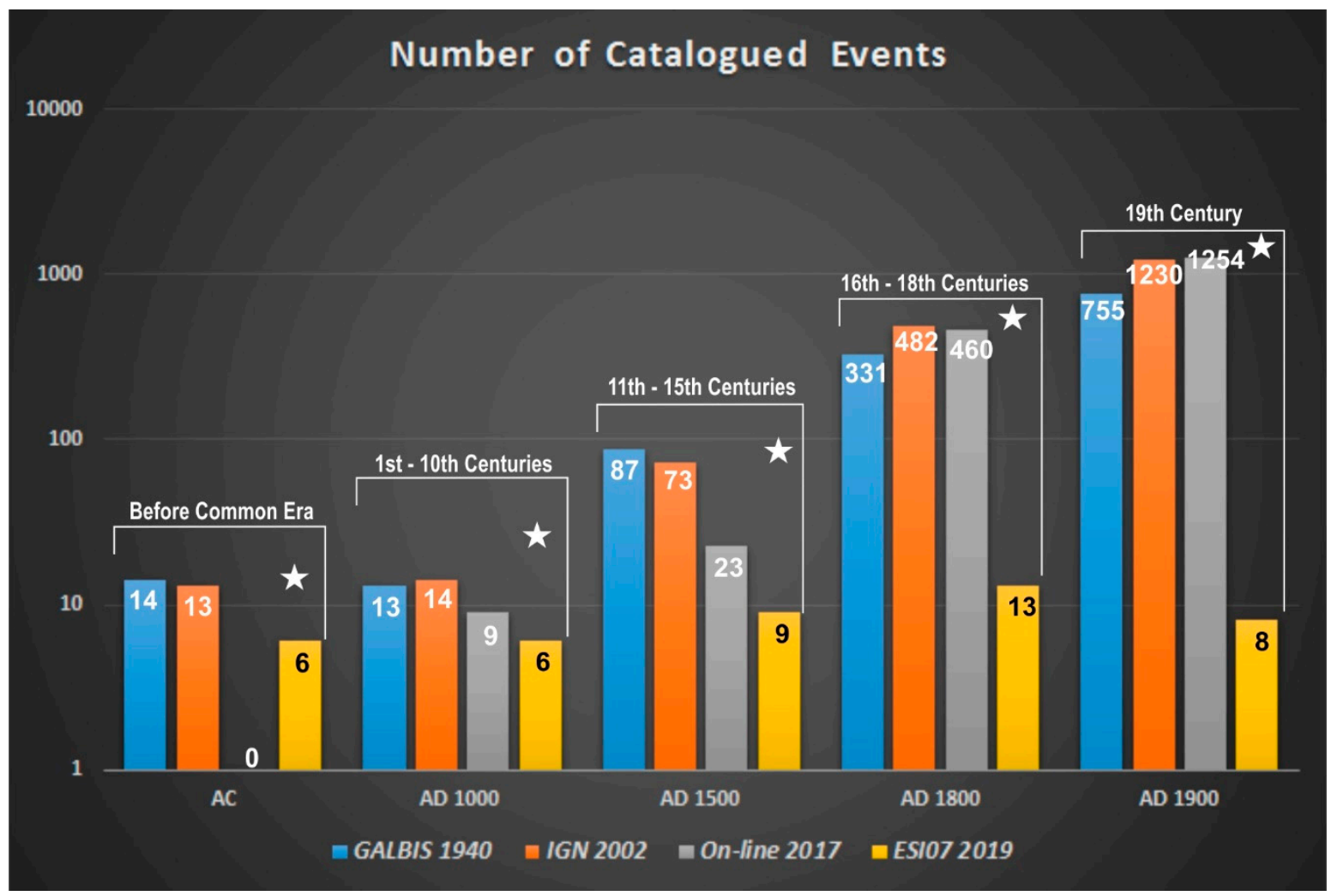

Figure 4. Number of catalogued earthquakes in the different seismic catalogues of Spain for different temporal periods. Stars and yellow bars identify the strong earthquakes included in ESI-07 Catalogue for the Iberian Peninsula [10] reviewed in this paper.

Figure 4 displays the evolution on the number of earthquake events catalogued for the different historic periods of interest discussed here. It is evident than independently of the nature of seismic information (written sources, archaeological or geological), there is a clear incompleteness of the record of seismic events before the year $1500 \mathrm{CE}$, and especially for those that occurred prior to $1000 \mathrm{CE}$. This is a typical artifact present in nearly all the seismic catalogs for the Mediterranean region [33].

These modern seismic practices largely contrast with the increasing number of ancient events recovered from paleoseismological and archaeoseismological studies for the visigothic, roman, phoenician periods and earlier ones (i.e., Bronze Age, Neolithic) [10] in Spain. It is for these ancient periods that geological and archaeological information is critical to recuperate old "lost events" no documented by written sources, leading to expand the seismic catalogues to the most recent geological record [34]. As evidence of these trends, since the end of the compilation of information for the published catalogue, three more ancient earthquakes were recovered. This is the case of the roman events of Idanha (Portugal) and Mulva-Munigua (Sevilla) that occurred during the 4th-5th centuries CE [35,36], as well as the suspected seismic event of Phoenician age (7th century BCE) documented in the Lower Segura Basin at Alicante [37].

Nevertheless, the geological and archaeological research of historical earthquakes has also been largely incorporated in the published catalogue, especially that related to damage to the historic heritage. This ESI-based investigation complements the EMS data allowing upgrading and completing macroseismic information especially in the county-side and depopulated areas, as does the geological investigation of instrumental earthquakes. This last will help to improve and refine data to update the ESI-07 scale in the future, but also to understand the assemblages and patterns of oriented building damage in relation to well-constrained seismic sources by instrumental data, as was the case of the 2011 Lorca earthquake in Spain [22,38]. 
The different nature of the information incorporated in the catalogue made necessary the use and combination of different types of macroseismic scales or classifications, such as the earthquake environmental effects (EEEs) of the ESI-07 scale, the destructive effects, or the tsunami environmental effects (TEEs) recently classified in the TEE-16 Scale [39]. These last are a complement and refinement to the ESI-07 scale on paleo-tsunami records. In the same way, the archaeological record of earthquake archaeological effects (EAEs) scaled in the works of Rodríguez-Pascua et al. [13,40] have been considered. Regarding EEEs in the ESI-07 scale, the Spanish catalogue [10] differentiates between tsunami effects (TSU) and anomalous waves (AW) in inland water bodies, such lakes, dams, rivers, etc. (Figure 1). In the same way, ESI-07 hydrologic effects have been split in two different categories: (1) hydrological effects (HA) such as changes in level or flow rates in water wells, springs and fountains; and (2) hydrogeological effects (HD) related to changes in physico-chemical properties, temperature, turbidity, etc. The rest of secondary EEEs, such as ground cracks (GK), slope movements (SM), liquefaction (LIQ) and other effects (OT), maintain their status and meaning as originally defined in the ESI-07 scale (Figure 1) [3].

\section{Quality of the Seismic and Geological Information for the Catalogued Earthquakes}

For all the catalogued earthquakes, source location parameters (date, origin time and geographical coordinates) correspond to those published in the catalogue of historical earthquakes of the IGN [7], except for those events not catalogued by this institution. Likewise, we consider convenient to introduce the indicative quality parameters on the "epicentral source location" (Qe) and "maximum epicentral intensity" (Qi) implemented for the abovementioned IGN catalogue, as well as the evaluation of the related theoretical "Moment Magnitude" (Mw) estimated by means of empirical relationships of magnitude-intensity specifically developed for that catalogue [7]. In spite of the publication of more recent source location and size parametric data on the historical and pre-instrumental seismicity for Spain [41], we preferred to keep the original source parameters listed in the official catalogue and databases of the IGN $[7,23]$ since the new published data are not official data.

\subsection{Quality of Source Location Determinations (Qe)}

Regarding the source location data, the geographical coordinates of the macroseismic epicenters are given as sexagesimal degrees and full minutes, equivalent to a precision of about $\pm 1.5 \mathrm{~km}$ sufficient for the entire historical catalogued period [7]. However, for the most recent earthquakes that have occurred since the year 1900 more detailed source location data were extracted from the IGN databases [23].

The quality parameter for the source location (Qe) presents five different classes with the following quality indexes:

- Quality A (location error $<10 \mathrm{~km}$ ): macroseismic epicenter surrounded by several macroseismic data-points, whose density allows estimating the source location with an uncertainty $\pm 5 \mathrm{~km}$. This category, of course includes those earthquakes instrumentally recorded after the year $1963 \mathrm{CE}$ (labelled as Quality I).

- Quality B (location error $<20 \mathrm{~km}$ ): macroseismic epicenter defined by a small number of macroseismic data-points, which density allows estimating the source location with an uncertainty $\pm 10 \mathrm{~km}$. The epicentral determinations for some of the earthquakes recorded between 1900 and 1963 CE (Spanish pre-instrumental period) are very imprecise and most of the events occurred in that period hold B quality (some even C).

- Quality C (location error 20-50 km): macroseismic epicenter located in a continental area defined by a single macroseismic data-point or by a few ones very distant each other. These can present an uncertainty above $\pm 25 \mathrm{~km}$, normally within a radius of $50 \mathrm{~km}$.

- Quality D (location error $>50 \mathrm{~km}$ ): macroseismic epicenter located in a coastal locality as the unique macroseismic data-point, or those that occurred offshore which can be poorly defined assuming location uncertainties above $\pm 25 \mathrm{~km}$. This quality-class also includes very ancient 
historical earthquakes recorded by vague and generic written descriptions refereed to very broad regions, such as Gulf of Cádiz, Atlantic Ocean, Mediterranean coast and the Pyrenees. This is the general case for most of the catalogued historical earthquakes before the 10th century BCE around the Iberian Peninsula.

- Quality Q (location error $<20 \mathrm{~km}$ ): Events not recorded by written sources with an only point, or very few points with archaeoseismic and/or paleoseismic information. This quality-class includes those earthquakes with limited archaeoseismic information indicating ground shaking (building fabric EAEs) or occasional paleoseismic information related to secondary earthquake environmental effects (EEEs), avoiding the identification of any reliable epicenter. In these cases, the provided geographical coordinates correspond to the more relevant archaeoseismic or paleoseismic data-points related to the catalogued event. In most cases, these correspond to near-field effects occurring to epicentral distances down to $20 \mathrm{~km}$, and by the acquired experience, the uncertainty would be even down to $\pm 5 \mathrm{~km}$ considered for the "Quality $\mathrm{A}^{\text {" events. }}$

- Quality $\mathrm{G}$ (location error $<10 \mathrm{~km}$ ): The available information is only of geologic nature, providing the geographical coordinates to the investigated points with paleoseismic information regarding primary EEEs of the ESI-07 scale, such as surface ruptures, fault scarps or fault-trenching analysis defining the seismic source. Consequently, this quality-class may hold more accurate locations than the "Quality A" events. In the case of the record of an important number of secondary EEEs the provided geographical coordinates are those corresponding to the zones where EEEs display largest dimensions, frequency or number (consequently intensity). These zones generally define areas no larger than a few squared kilometers wide, where the true macroseismic epicenters are located. This is not valid for strong offshore events or zones with an important proved susceptibility to ground shaking amplification.

These two last quality-classes ( $Q$ and $G$ ) were introduced in the Catalogue of geological effects of earthquakes by Silva et al. [10,12], whilst the previous classes (A, B, C, and D) are those already developed for the Catalogue of historical earthquakes in Spain [7]. Classes $Q$ and $G$ also include the generic date of the earthquake as provided by the battery of isotopic dates $\left({ }^{14} \mathrm{C}, \mathrm{Th} / \mathrm{U}, \mathrm{OSL}, \mathrm{TL}\right.$, ESR, etc.) available for the archaeoseismic or paleoseismic data-points, as well as morphometric or archaeological relative dates for particular cases.

\subsection{Quality of Earthquake Intensity Assessments (Qi)}

The new published Spanish ESI-07 catalogue introduces the maximum intensity value assessed from the ESI-07 scale, but earthquake intensities estimated from other macroseismic scales are also listed and considered. This is the case for the intensity values corresponding to the European Macroseismic Scale (EMS-98) [7] and the Mevdéved-Sponheuer-Karnik Scale (MSK-81) applied in previous Spanish catalogues [42]. As is known, the MSK and EMS scales are nearly equivalent, with the exception that EMS mainly considers building damage, with the exclusion of environmental damage and geological effects of earthquakes for intensity assessments, which is one of the causes for the development of the ESI-07 scale [2].

It is also convenient to indicate that the EMS-98 scale does not consider damage on buildings of historical heritage (Castles, Fortress, Cathedrals, Old Churches, etc.) for intensity assessments [4]. This is a serious inconvenience for evaluating the intensity of historical earthquakes for which the most complete information comes from the description of the damage that occurred in this type of building. This fact has an important impact for earthquakes that occurred before AD 1500, for which written documentation is sparse, and only the analyses of EAEs preserved in these patrimonial buildings or archaeological sites allow estimating the earthquake size [38]. Accordingly, intensity assessments developed for the catalogue display better similarity to those of the ancient catalogues with the MSK scale than the most recent ones based on the EMS scale. In general, an old maximum intensity IX MSK is nowadays converted in a maximum intensity VIII-IX or VIII EMS in the most recent catalogues and databases of the IGN $[7,23]$. This generally occurs for most of the historical earthquakes between VIII 
and X intensity in the previous MSK catalogues. This means that the application of the EMS-98 scale in Spain resulted in the reduction of one to half degree with respect to those corresponding to the MSK-81 or ESI-07 scales, which has special negative incidence in the more recent SHA studies in Spain [11]. These evaluate horizontal ground accelerations from the conversion of EMS intensities from historical events (last 450 years) by means of complex combinations of empirical relationships developed for other traditional (i.e, MM or MCS) macroseismic scales, inducing very probable underestimations for the ground movement [19]. As stated in the published catalogue [10], the EMS-98 scale is a nice technical guide for the quantification of building damage produced by recent earthquakes, but of limited application for historical events. Data on old historical events in Spain mainly provide information on environmental damage and significant buildings, now catalogued in the national cultural heritage lists, and the EMS scale does not consider damage on historical buildings and environmental effects for intensity assessments [4]. It is necessary to note that the intensity degrees $\geq$ IX EMS-98 mainly base the intensity assessments on the effects on metallic structure buildings or quake-resistant ones, since the rest of buildings are destroyed at this stage. However, these types of buildings are virtually absent for all the historical periods of Spain, where the first modern seismic code was introduced at the end of the 20th century in the year 1994 (NCS-94). Consequently, the EMS-98 scale has a poor application for historical earthquakes not only in Spain, but also for most of the European territory.

The published catalogue attempts to document and graphically illustrate (photos, diagrams, sketches, drawings, maps, etc.) in the most exhaustive mode possible the large variety of EEEs recorded during the 51 stronger events that occurred in Spain. These have normally intensities $\geq$ VIII for the pre-instrumental period, but some well-documented events of intensity VII that occurred after the year 1900 produced significant EEEs (Table 1). Nevertheless, the catalogue also lists the other important earthquake size parameter: the magnitude. In this case, all the events before the year 1900 have estimated magnitude $(\mathrm{Mw})$ values coming from empirical relationships published in previous Spanish catalogues or recent scientific papers. In many cases the estimated Mw values may appear as bracketed values (i.e., 6.2-6.6) since published data provide different, but similar, magnitude values. This is relevant for those earthquakes only catalogued from paleoseismological data after fault-trenching analyses, where Mw evaluations came specifically from empirical relationships based on the work of Wells and Coppersmith [43]. Instead, events that occurred after the year 1900 are instrumentally recorded and magnitude values are well constrained.

In this way, the catalogue differentiates several quality classes in relation to the maximum known or geologically recorded intensity using the ESI-07 scale. In addition to the intensity points assessed by means of EEEs or EAEs, quality class also considers all macroseismic data-points with EMS information. The quality classes (Qi) are the following:

- Quality A: Density of points with macroseismic information is sufficient to undertake reliable intensity assessment. Normally, this class includes those earthquakes with more than 30 data-points, which generally refers to events that occurred after the 17th century CE.

- Quality C: The available points with macroseismic information are insufficient to undertake reliable intensity assessments. In some cases, there is a single data-point. These earthquakes include old events historically documented, but with little to no geological information, normally occurring before the year $1000 \mathrm{CE}$.

- Quality B: The accuracy of the intensity assessments is between the two previously mentioned quality classes. This is normally the case of those events that occurred between the 10th and 17th centuries CE. However, for some of them, macroseismic data-points are up to 15-20, including a variety of geological information on secondary EEEs.

- Quality D: EEEs ambiguously or roughly described in historical documents in reference to a region instead to particular localities, which lack modern geological studies. This is normally the case of all the catalogued events for the first millennia of the present era, but also most of the earthquakes that occurred before the present common era, with poor to no geological evidence. Descriptions such as "mountains and plains opened; the earth guzzled and engorged villages and hills; the sea 
shrank away, islands and islets disappeared; many villages in the southern and western coasts of Spain were totally ruined", characterize this type of events. This corresponds to the translation of original Arabic text for the 881CE earthquake affecting the old Al-Andalus in South Spain.

- Quality G: EEEs related to historical or prehistoric events, normally not included in the conventional seismic catalogues. They are only documented by geological information coming from recent scientific paleoseismic and archaeoseismic published papers. In general, this quality class includes earthquakes that occurred during the first millennia of the present common era, particularly those that occurred during the Roman and Visigoth period in Spain, but also those only geologically documented.

- Quality I: EEEs linked to recent earthquakes that occurred during the 20th century and the onset of the 21st century. These events are instrumentally recorded and geological effects have been documented "in situ" after the earthquake by scientific commissions or groups of earthquake geologists interested in the event. This quality class normally has the best Qe, Qi and Qg quality indexes. However, as aforementioned some of the pre-instrumental period events (1900-1962 CE) have a poor Qg index with poorly defined descriptions of geological effects, similar to those of Quality B.

\subsection{Quality of the Geological Information $(Q g)$}

The published Spanish catalogue introduces a third quality index related to the value of available information on geological and environments effects of the earthquakes (EEEs) listed in the ESI-07 Scale. This quality index was specifically developed for this catalogue and considers the following quality classes:

- Quality A: EEEs widely documented by technical or field reports, scientific papers and journals of the earthquake epoch that have undergone modern geological research published in scientific papers, allowing the quantification of primary and or secondary effects. Generally, this class includes those events that occurred after 1800 CE (19th century), although some 18th century events were also well documented in this time (i.e., 1755 CE Lisbon Earthquake).

- Quality B: EEEs vaguely described in historical documents, but subject of modern published geological research. These events mainly correspond to those that occurred between the 15th and 19th centuries and most of those that occurred during the so-called "pre-instrumental period" in Spain (1900-1962 CE). These normally have good Qe and Qi indexes, but poor geological information, since the progressive implementation of seismographs in Spain during the first half of the 20th century resulted in increasingly worse field-reports.

- Quality C: EEEs ambiguously or roughly described in historical documents in reference to a region instead to particular localities, which lack modern geological studies. This is normally the case of all the catalogued events for the first millennia of the present Common Era, but also most of the earthquakes that occurred before the present Common Era, with poor to no geological evidence, with historical descriptions similar to that transcribed for the Quality C events of the Qi index.

- Quality G: EEEs related to historical or prehistoric events, normally not included in the conventional seismic catalogues. They are only documented by geological information coming from recent scientific paleoseismic and archaeoseismic published papers. In general, this quality class includes earthquakes that occurred during the first millennia of the present common era, particularly those that occurred during the Roman and Visigoth period in Spain, such as those recorded in Baelo Claudia [44], but also those only geologically documented.

- Quality I: EEEs linked to earthquakes that occurred during the 20th century and the onset of the 21st century. These events are instrumentally recorded and geological effects have been documented "in situ" after the earthquake by scientific commissions or groups of earthquake geologists interested in the event. This quality class commonly holds the best Qe, Qi and Qg quality indexes. However, as aforementioned some of the events of the pre-instrumental period 
(1900-1962 CE) have a poor Qg index with poorly defined descriptions of geological effects, similar to those of Quality B events.

\subsection{Overall Quality for Earthquake Information}

Taking into account these three different quality indexes (Qe, Qi, Qg) we have different quality-type events for which macroseismic information allows labelling the earthquakes as credited or poorly credited. In this way, "triple A" (AAA) and "triple I" (III) events can be considered as fully credited events with the most accurate assessments for source location, date and intensity. However, GGG and GQG events are credited with a similar quality than the AAA ones, these are also well-constrained events, but source locations in the near field are still doubtful (Tables 1 and 2). On the contrary, CCC or DCC events are the poorly constrained events. In fact, most of this type of events included in the ESI-07 catalogue [10] have been recently removed from the official macroseismic databases of the IGN [23]. In that exercise, some of the well constrained geologically documented GGG, BGG or QGG earthquakes included in the new published catalogue [10] were also removed from the official macroseismic databases, since these still do not consider geological information [8]. This is the case of the 218 BCE Lacus Ligustinus event, which aside from being historically documented, has been identified by tsunamite deposits in all the littoral spit-bars and marshlands of the Gulf of Cádiz, as well as in offshore turbidite deposits near the suspected earthquake source area [28-32]. Whatever the case, all the double $\mathrm{AA}$, double $\mathrm{BB}, \mathrm{AB}$ or $\mathrm{AI}-\mathrm{BI}$ events certainly occurred, but source parameters present some uncertainty. Only those labelled as CCC or some DCC are doubtful events (Table 2). These mainly correspond to those that occurred before the present common era (BCE) which are vaguely documented by historical written reports in relation to the first Phoenician and Greek settlements on the Spanish coast, around or fairly before the $500 \mathrm{BCE}$ in the Pyrenees (Emporium) and the Gibraltar Strait (Gadir).

\section{Event Files: Summarized Information for the 51 Catalogued Earthquakes}

The information for each catalogued event has been summarized in a two-page file format (Event files) with one-page versions in Spanish and English (Figure 5). These files are available for the 51 catalogued events. They display a numerical summary of the abovementioned source and size parametric data and quality indexes. In the case of instrumental events (INS Code), data on source depth, location errors, recorded magnitude and occurrence of foreshocks and aftershocks is also included in the parametric summary. The maximum intensity in the different scales applied in Spain (MSK-80, EMS-98 and ESI-07) are displayed for all the events, as well as summarized data on the number and size of catalogued EEEs and significant EAEs where pertinent. Event files also include a numerical list of the historical documentation referring to the catalogued earthquake listed in the official catalogue of the IGN [7], as well as five to six key bibliographic references documenting earthquake environmental and building damage.

All the events have a Spanish "resumen" and an English "abstract" summarizing the type and number of the ESI-07 catalogued EEEs, as well as a brief description of the extension/nature of environmental damage (ESI-based) and general information on affected localities and building damage (EMS-based). The info also includes the location of the earthquake within the different "seismotectonic zones" (GM12 Zones) defined for the new "Upgraded Seismic Hazard Maps for Spain" elaborated after the 5.1 Mw 2011 Lorca earthquake to update the present Spanish Seismic Code [11]. Additionally, the "Event files" include a simplified geological map of the Iberian Peninsula displaying the location of the earthquake epicenter within the different structural units of Spain depicted in Figure 2: Alpine Cordilleras (Betics, Pyrenees, Iberian range, Catalan ranges); Palaoezoic-Variscan massif (west Iberia); and Cenozoic sedimentary basins (Tagus, Duero, Guadalquivir, Ebro basins). In the endnote of each "Event file" are displayed the name(s) and affiliation(s) of the author(s) in charge of the compilation and structuring of the macroseismic information. 
GEO 001AC 218: LACUS LIGUSTINUS (Océano Atlántico). 218 - 209 AC GEOLógICO

\begin{tabular}{|c|c|c|c|c|c|c|c|c|c|c|c|c|c|}
\hline $\begin{array}{l}\text { FECHA } \\
\text { AMD }\end{array}$ & $\begin{array}{l}\text { HORAY } \\
\text { MIN. }\end{array}$ & LONGITUD & LATITUD & \multicolumn{2}{|c|}{$\begin{array}{c}\mathrm{MAG} \\
\left(\mathrm{Mw} / \mathrm{Ms} / \mathrm{M}^{*}\right)\end{array}$} & $\begin{array}{c}\text { EMS } \\
98\end{array}$ & $\begin{array}{c}\text { MSK } \\
64\end{array}$ & $\begin{array}{c}\text { ESI } \\
07\end{array}$ & $Q_{e}$ & $Q_{i}$ & $\mathrm{Q} g$ & \multicolumn{2}{|c|}{ LOCALIZACIÓN TERREMOTO } \\
\hline $218-209 A C$ & - & $9^{\circ} 42^{\prime} \mathrm{O}$ & $36^{\circ} 38^{\prime} \mathrm{N}$ & \multicolumn{2}{|c|}{$8,0 \mathrm{M}^{*}$} & - & - & $\mathrm{x}$ & G & G & G & \multicolumn{2}{|c|}{$\begin{array}{l}\text { Lacus Ligustinus. } \\
\text { SW Cabo de San Vicente (0. } \\
\text { ATL.) }\end{array}$} \\
\hline \multicolumn{2}{|c|}{ Método de datación: } & \multicolumn{10}{|c|}{$\begin{array}{l}\text { CATALOGADO } \\
\text { Ref. Bibliográfica: Galbis (1932), Luque et al. (2002), Lario et al. (2011), Rodriguez Vidal et al.(2011) }\end{array}$} & $\begin{array}{l}\text { Tipo } \\
\text { Evento: }\end{array}$ & GEO (HST) \\
\hline Prof. km & & $\pm E Z$ & $\pm \mathrm{EH}-$ & Mo & & & \multicolumn{3}{|c|}{ Eventos asociados } & & & Agencia: & IGN \\
\hline \multicolumn{2}{|l|}{ EEE Primarios } & NO & \multicolumn{2}{|c|}{ Longitud Falla } & - & & \multicolumn{3}{|c|}{ Desplazamiento } & - & & $\begin{array}{l}\text { Tipo } \\
\text { Desp.: }\end{array}$ & SIN DATOS \\
\hline \multicolumn{2}{|c|}{ EEE Secundarios } & sí & \multicolumn{2}{|c|}{ Categoría ESI07 } & \multicolumn{7}{|c|}{$\square \mathrm{GK}$ 凶SM $\square \mathrm{LQ} \square \mathrm{HD} \square \mathrm{HA} \square \mathrm{WA}$ ⿶TS } & $\begin{array}{l}\text { Area } \\
\text { afectada: }\end{array}$ & $\begin{array}{l}>2.500 \mathrm{~km}^{2} \\
\text { (Litoral Español) }\end{array}$ \\
\hline \multicolumn{2}{|c|}{ Otros EEE Ambientales } & NO & \multicolumn{11}{|c|}{$\begin{array}{l}\text { Q OTROS EFECTOS (OT): Las descripciones indican una retirada y posterior inundación marina de envergadura que } \\
\text { provocó serios daños y mortalidad en la fauna marina: "se arrojaron fuera del mar multitud de pescados". }\end{array}$} \\
\hline \multicolumn{2}{|c|}{$\begin{array}{l}\text { EAE Efectos } \\
\text { Arqueosismológicos }\end{array}$} & NO & \multicolumn{11}{|c|}{$\begin{array}{l}\text { EAEs: Antiguos asentamientos humanos anteriores al } \\
\text { litoral del antiguo Lacus Ligustinus romano (Marismas de D }\end{array}$} \\
\hline \multicolumn{14}{|c|}{ Documentación IGN 2002: $165,166,280,335,405,426,504,545,687$} \\
\hline \multicolumn{14}{|c|}{ 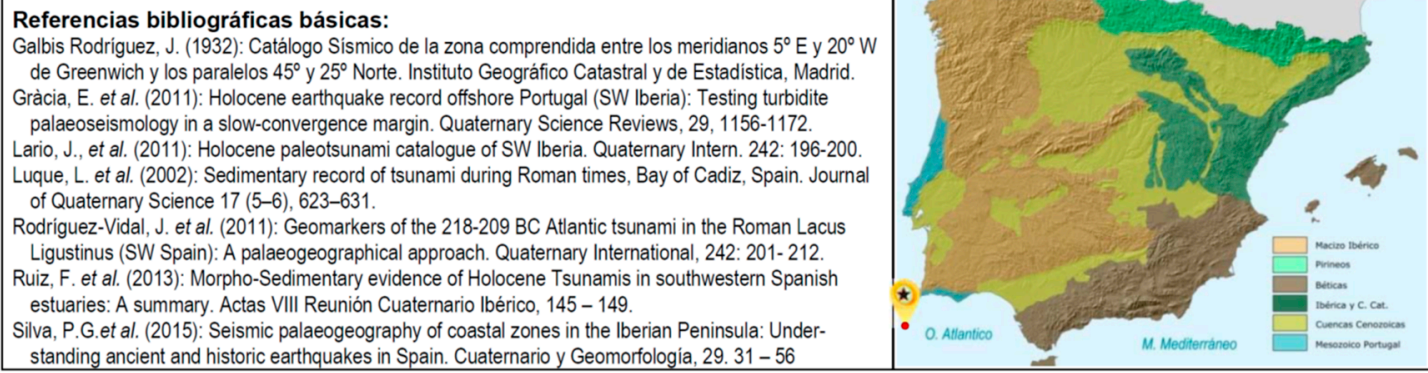 } \\
\hline
\end{tabular}

\section{EARTHQUAKE ABSTRACT}

\begin{tabular}{l|c|c|c|c|c|c|c|c|c|}
\multicolumn{1}{c|}{ EVENT } & LONGITUDE & LATITUDE & $\begin{array}{c}\text { MAG } \\
\text { (Mw/Ms/M*) }\end{array}$ & $\begin{array}{c}\text { EMS } \\
98\end{array}$ & $\begin{array}{c}\text { MSK } \\
64\end{array}$ & $\begin{array}{c}\text { ESI } \\
07\end{array}$ & $\mathrm{Q}_{g}$ & \multicolumn{2}{c|}{ SEISMOTECTONIC ZONE IGN 2012 (GM12 ZONES) } \\
\hline $\begin{array}{l}\text { GEO 001BC } 218 \\
\text { Lacus Ligustinus. } \\
\text { SW Cabo de San Vicente }\end{array}$ & $9^{\circ} 42^{\prime} \mathrm{W}$ & $36^{\circ} 38^{\prime} \mathrm{N}$ & $8.0 \mathrm{M}^{*}$ & - & - & $\mathrm{X}$ & $\mathrm{G}$ & \multicolumn{3}{|c}{ Atlantic Ocean; Gorringe Bank (Zone 52) } \\
\hline
\end{tabular}

\begin{tabular}{ll|l|l} 
Ref.: Galbis (1932), Luque et al. (2002), Gràcia et al. (2010), Lario et al. (2011), Rodriguez Vidal et al. (2011), Ruiz et al. (2013) & $\begin{array}{l}\text { Event } \\
\text { Type: }\end{array}$ & GEOLOGIC (HST) \\
\hline
\end{tabular}

GENERAL DAMAGE: Earthquake felt in all the Atlantic littoral of the Gulf of Cadiz (SW Spain) especially affecting to the ancient town of Cadiz (Gades) in that time most important locality of the area located in an island within the estuary of the Guadalete river. The description of the event by Galbis (1932), extract from the historic chronicles of Florián de Ocampo (1553) indicate that "The island of Cadiz, but also all the littoral zone of Andalucia suffered strong earthquakes or tremors, inducing the collapse of buildings, the death of the inhabitants and producing terrible wrongs; the sea flooded many places that were first uncovered by the waters, throwing out a multitude of fishes, some of them common but others never seen". This historical chronicle is in the context of the initiation of the surprising overland journey of Hannibal Barca from Quart Hadast (Carthago Nova) across the Alps to Rome in the beginning of the Second Punic War (218 BC).

ENVIRONMENTAL DAMAGE: The historical descriptions indicate the occurrence of an earthquake generating tsunami, which severely affected the littoral in the Gulf of Cadiz, and especially the old insular emporium of Gades (Cádiz). There are no descriptions associated with earthquake damage, but a relatively good geological record of tsunami deposits associated with both coastal estuarine Tinto-Odiel (Huelva); Guadalete (Cádiz) and the Guadalquivir marshes (Doñana) and in ocean turbiditic levels (submarine landslides) recorded near the Gorringe Bank. Core data from coastal areas document centimeter-thick high energy laminar deposits (tsunamites), with a mixture of estuarine and marine fauna (planktonic and benthic), recorded as far as 12 to $17 \mathrm{~km}$ inland from the present coastline. Geological data indicate the occurrence of a tsunami of at least $5 \mathrm{~m}$ (run-up) causing significant environmental damage in the aforementioned estuarine zones, such as breakage of spits-bars, changes of drainage patterns within the marshlands and important erosion phenomena on beaches and coastal dune systems (Doñana), comparable to those produced by the AD 1755 Lisbon earthquake-tsunami event. Geological data indicate the record of X ESI-07 intensity, along at least the c. $140 \mathrm{~km}$ separating the Tinto-Odiel (Huelva) and the Guadalete (Cádiz) estuaries.

$\square$ Surface ruptures (SR): No Reported.

Tectonic uplift / subsidence (UP): No Reported.

Ground cracks (GK): No Reported.

3 Slope movements (SM): Submarine landslides in the vicinity of the Gorringe Bank (Atlantic Ocean) around the suspect epicentral area. The event is recorded as turbidite levels, up to $20 \mathrm{~cm}$ thick in 3 of the 4 drill-cores conducted in the area.

$\square$ Liquefaction processes (LO): No Reported.

Dydrogeological anomalies (HD; HA): No Reported

Q 7 Anomalous Waves and Tsunamis (7 TS): Record of tsunami deposits, and sedimentary levels produced by erosion-reworking of coastal beaches and spit-bars in the Tinto-Odiel estuaries (2 core-probes) and Guadalquivir marshlands (Doñana, 5 core-probes). Washover fans in the Guadalete estuary and Valdelagrana spit-bar (Cádiz; 2 records). Different effects associated with both the tsunami erosive record and/or backwash under study to be catalogued.

Q 1 Other effects: Significant retreat and subsequent flooding by the sea of coastal areas, causing serious damage and mortality of the marine fauna.

1 Archaeoseismic damage: Some coastal pre-Roman ( $7^{\text {th }}$ - $3^{\text {rd }}$ centuries BC) human settlements around the ancient Lacus Ligustinus (Doñana marshlands), were abandoned (i.e. La Algaida), and later, after the tsunami new Roman saltworks were installed from the ${ }^{1 \text { st }}$ century $A D$.

$\triangle$ Geological Data: There is and relevant geological record on the occurrence of a significant tsunami event in the more important estuarine zones of the Gulf of Cádiz. ${ }^{14} \mathrm{C}$ dating indicate the occurrence of a tsunami during roman times with a run-up of $5 \mathrm{~m}$. bracketed in 218-210 BC (Lario et al., 2011: Rodriguez Vidal et al., 2011). Date from offshore drill-cores around the Gorringe Bank (suspect seismic source) record different tsunami-type events triggering submarine landslides of Holocene age (Gràcia et al., 2010). Three of the four cores conducted in the area record the roman event (Event 5; E5) dated in 1,980-2,280 yr. BP, with an estimated magnitude $\geq$ (Gràcia et al., 2010). Three of the four cores conducted int
$8,0 \mathrm{Mw}$. Quality of Geological Information: Class G.

Research / Data compilation by: Pablo G. Silva (USAL); Javier Lario (UNED). Updated 2019.

Figure 5. Example of an Event file (English version) produced for the 51 catalogued events. This corresponds to the 218 AC Lacus Ligustinus earthquake [28] with historical, geological and archaeological records. 
The 51 catalogued events appear listed and ordered temporally (by date). Each "Event file" displays a code identifying the type of catalogued event (GEO, ARQ, HST, PRE or INS) followed by the corresponding date in numerical format YYYYMMDD (year/month/day); as an example, the most recent event catalogued, the 2011 Lorca earthquake has the code INS 20110511 (Table 1). The code for paleoseismic (GEO), archaeoseismic (ARQ) or historical (HST) events that occurred before the present Common Era (BCE or $\mathrm{BC}$ ), for which there is only information of the year, the code identifies the millennia and the year (Table 2).

In the case of paleoseismic events with bracketed ages resulting from the uncertainty errors of the applied dating method documenting the earthquake always use the more recent date (year). As an example, the date of the most ancient catalogued earthquake (La Cueva del Toro, Antequera, Málaga) is bracketed by ${ }^{14} \mathrm{C}$ dating in the fourth millennia BC (4200-3700 BCE) and has the code ARQ 04 3700BC (Table 2). Figure 5 displays the structure and format of the English version of the "Event files" included in the published catalogue.

\section{Full Event and EEE Files: Full Information for Selected Catalogued Earthquakes}

The second edition of the catalogue offers full information for 16 selected events representative of each earthquake type or period (GEO, ARQ, HST, PRE, INS). For these events, a complete analysis of the catalogued environmental (EEEs) or archaeoseismological (EAEs) effects is available. A total amount of 1027 effects has been identified of which 840 are EEEs and 187 EAEs. From this large amount of catalogued effects, about 680 are briefly analyzed in "Event files" and 322 in detailed individual "EEE files" (Figure 6). These last cover all the typologies of EEEs observed in the ESI-07 scale [3], including 84 tsunami effects analyzed by means of the upgraded TEE scale [39]. Some of the earthquakes with a large amount of information over the 75 effects, such as the 2011 Lorca (79 EEEs), 1829 Torrevieja (78 EEEs) and 1755 Lisbon (674 EEEs) have been simplified to a representative number of about 45-50 "EEE files".

Aside from the information summarized in the "event file", earthquakes with complete information have a section in which the original descriptions of the early seismic catalogues for Spain (e.g., Galbis Catalogues) are literally transcribed including the prime references used by Galbis [45]. The "full event files" also include descriptive and interpretative sections in which the source location and maximum intensity of the earthquakes are evaluated in relation to the catalogued EEEs, EAEs, and data from other recent scientific publications. In those cases in which published geological data, ESI-07 parametric evaluations (EEEs) or archaeoseismic oriented damage (EAEs), point to different source locations than those listed in the IGN catalogue [7] the parametric data of the earthquake is disused in the interpretative section. For those recent earthquakes not included in the Galbis catalogues [45], previous to AD 1940, the section of the original descriptions by Galbis have been substituted by a section of "general information" summarized from available seismic reports or field reports developed by different institutions (IGN; IGME; IAG or Civil Protection). For ancient or paleoseismic events not catalogued by Galbis [45], the general information section includes data on the archaeological site or fault-trench site documenting the respective earthquakes. The descriptive and interpretative sections for these full-information events are structured in the style of four-five-page short papers and include a complete reference list of historical sources and recent scientific publications analyzing the corresponding earthquake. 


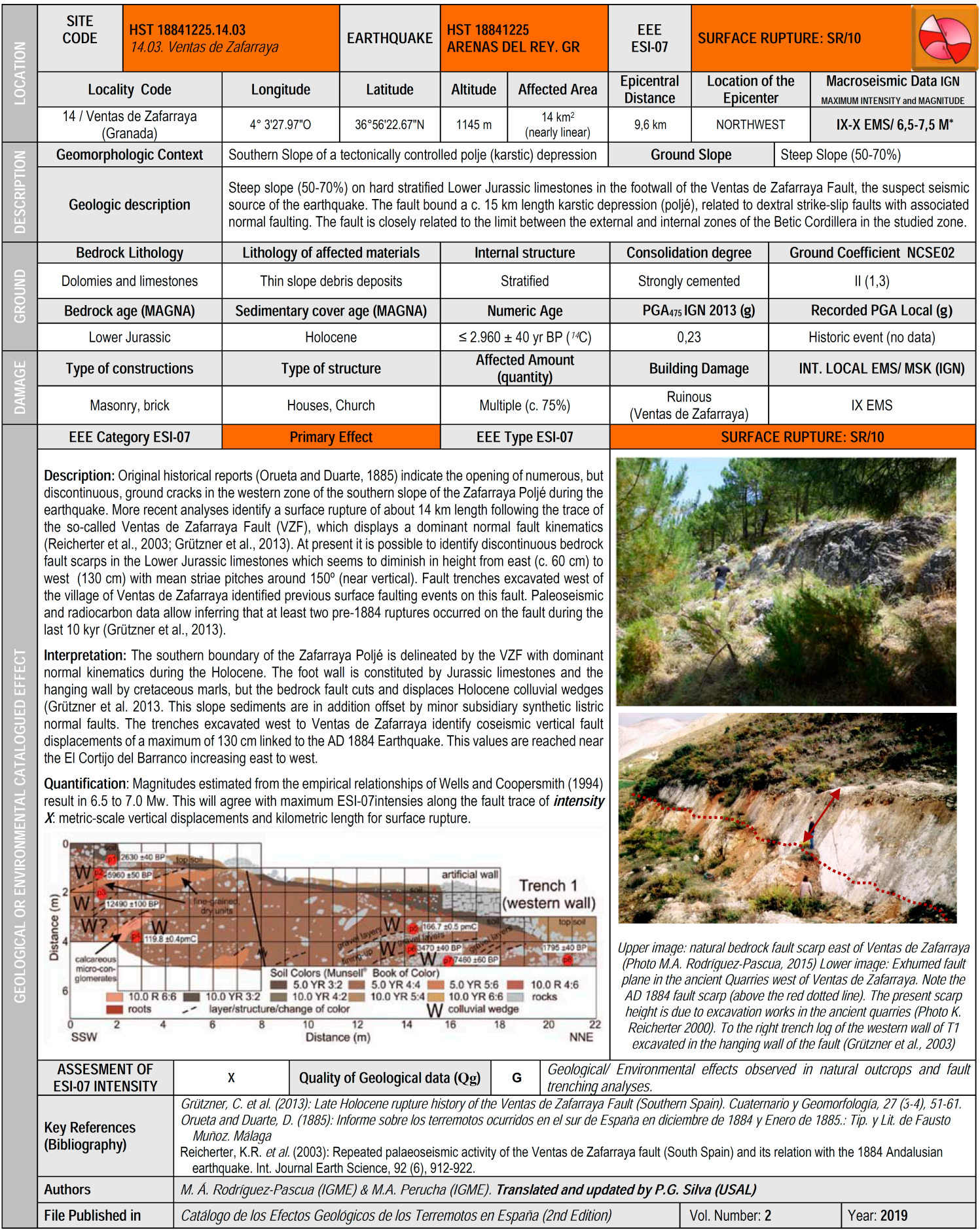

Figure 6. Example of an "environmental earthquake effects (EEE) file" produced for 16 selected earthquakes included in the Spanish Catalogue of geological effects of earthquakes [10]. The example corresponds to the surface rupture (primary effect) triggered by the AD 1884 Arenas del Rey earthquake (Intensity X). The file has been translated and updated for the present paper by P.G. Silva. Original EEE files are in Spanish.

\subsection{EEE Files: Detailed Information for Each Catalogued Event}

The detailed information of each catalogued EEEs or EAEs is implemented in individual "EEE files", which offer parametric macroseismic information on geographical coordinates, epicentral distances, epicentral orientation, affected area by the EEE $\left(\mathrm{km}^{2}\right.$ or $\left.\mathrm{m}^{2}\right)$ and the assessed local intensities (EMS/MSK) by building damage coming from previous catalogues. These "EEE files" also include normalized data 
on the local geomorphology (landscape context and terrain slope), geology (age and nature of affected material and substratum, if the case), but also geotechnical data. This latter information considers the different soil classes observed by the present Spanish Seismic Code [46], as well as normalized PGA values $(\% \mathrm{~g})$ considered by this seismic code for the affected zone. This geotechnical section also offers normalized descriptions for the construction-types, building-types, amount and damage level that occurred in the locality affected by the particular catalogued EEE in each individual "EEE file". In a last section the "EEE file" displays geological information on the category (primary/secondary), type (liquefaction, slope Movement, etc.) and ESI-07 intensity of the catalogued EEE, as well as individual abridged information on the description, interpretation, quantification (intensity assessment) and the particular Quality index $(\mathrm{Qg})$ of the catalogued effect. This ESI-07 section of the file also includes graphical information of the catalogued EEE, such as photos, drawings, sketches, maps, GoogleEarth imagery, etc., depending on the period of the corresponding earthquake. Finally, the "EEE files" offer four to five key bibliographic references that specifically document, describe or analyze the catalogued EEE. Figure 6 illustrates the above-described structure of the EEE/EAE files.

\subsection{Graphic Information Included in the "Full Event Files"}

The full event files content a variety of info-graphic data. The primary info is a parametric list of effects (EEEs and EAEs) identified for a specific symbol developed for the scale (see symbol effects in Figure 1) and ordered alphabetically by locality and locality-site when precise (Figure 7). Selected Google Earth images of the kmz files developed for each earthquake (Figure 8) illustrate these parametric lists. The kmz files (and selected views) identify each catalogued EEE or EAE type-effect by its corresponding symbols (Figures 7 and 8). In the future, these $\mathrm{kmz}$ event files will be uploaded in a public geo-information database of the Geological Survey of Spain (IGM) for the interactive on-line search of the entire catalogue. Additionally, the "full event files" include two basic graphic databases in form of intensity maps and seismic scenarios (ShakeMaps). When sufficient data hybrid ESI-EMS intensity maps were produced following the guidelines of the ESI-07 scale [3].

Información macrosísmica catalogada (catalogued macroseismic info)

\begin{tabular}{|c|c|c|c|c|c|c|c|}
\hline $\begin{array}{c}\text { Localidad/ Sitio } \\
\text { Locality / Site }\end{array}$ & $\begin{array}{c}\text { Longitud } \\
\text { Longuitude }\end{array}$ & $\begin{array}{l}\text { Latitud } \\
\text { Latitude }\end{array}$ & $\begin{array}{l}\text { Efecto } \\
\text { Effect }\end{array}$ & $\begin{array}{c}\text { Localización } \\
\text { Epicentral location }\end{array}$ & EMS-98 & MSK-64 & ESI-07 \\
\hline 01.01 Albojaira, Laguna de & $1055^{\prime} 42,677^{\prime \prime} 0$ & $37^{\circ} 20^{\prime} 29,76^{\prime \prime} \mathrm{N}$ & GK & N $2,8 \mathrm{~km}$ & No data & VI (Zone) & VIII \\
\hline 01.02 Albojaira, Laguna de & $1^{\circ} 55^{\prime} 42,67^{\prime \prime} 0$ & $37^{\circ} 20^{\prime} 29,76^{\prime \prime} \mathrm{N}$ & WA & $\approx \pi_{2} \mathrm{~N} 2,8 \mathrm{~km}$ & No data & VI (Zone) & VIII \\
\hline 02.01 Almanzora, Valle & $1{ }^{\circ} 53^{\prime} 13,00^{\prime \prime} 0$ & $37^{\circ} 17^{\prime} 50,71^{\prime \prime} \mathrm{N}$ & SM & $\approx \mathrm{NE} 1,9 \mathrm{~km}$ & No data & VI (Zone) & VII \\
\hline 02.02 Almanzora, Valle & $1957 ' 34,48 " 0$ & $37^{\circ} 23^{\prime} 17,79^{\prime \prime N} \mathrm{~N}$ & $\mathrm{HA}$ & $H_{1,0} \mathrm{NE} 1,2 \mathrm{~km}$ & No data & $\mathrm{Vl}$ (Zone) & VIII \\
\hline 03.01 Cuevas de Almanzora & $1^{\circ} 52^{\prime} 46,64 " 0$ & $37^{\circ} 17^{\prime} 49,30^{\prime \prime N}$ & GK & If $\mathrm{NNO} 8,9 \mathrm{~km}$ & $V-V I$ & V & VI \\
\hline 03.02 Cuevas de Almanzora & $1^{\circ} 53^{\prime} 9,08^{\prime \prime} 0$ & $37^{\circ} 17^{\prime} 58,55^{\prime \prime N}$ & SM & $\approx \mathrm{NNO} 8,5 \mathrm{~km}$ & $V-V I$ & V (Zone) & VI \\
\hline 03.03 Cuevas de Almanzora & $1^{\circ} 52^{\prime} 58,57 " 0$ & $37^{\circ} 17^{\prime} 49,50^{\prime \prime N}$ & EAE & NNO9,1 km & $\mathrm{V}-\mathrm{VI}$ & V & VI \\
\hline 04.01 Huércal-Overa & $1956^{\prime} 34,42^{\prime \prime} 0$ & $37^{\circ} 23^{\prime} 8,89^{\prime \prime} \mathrm{N}$ & $H D$ & $\mathrm{H}_{2} \mathrm{OSSE} 2,6 \mathrm{~km}$ & VI-VII & VII & VII \\
\hline 04.02 Huércal-Overa & 156'31,63"0 & $37^{\circ} 23^{\prime} 9,27^{\prime \prime N}$ & GK & STSE $2,3 \mathrm{~km}$ & VI-VII & VII & VI \\
\hline 04.03 Huércal-Overa & $1^{\circ} 56^{\prime} 31,63^{\prime \prime} 0$ & $37^{\circ} 23^{\prime} 9,27^{\prime \prime} \mathrm{N}$ & OT & Af SSE $2,4 \mathrm{~km}$ & VI-VII & VII & VII \\
\hline 04.04 Huércal-Overa & $1^{\circ} 56^{\prime} 36,19 " 0$ & $37^{\circ} 23^{\prime} 20,83^{\prime \prime N}$ & EAE & SSE $2,7 \mathrm{~km}$ & VI-VII & VII & VII \\
\hline 05.01 Huércal, Castillo & $1^{\circ} 56^{\prime} 4,41^{\prime \prime O}$ & $37^{\circ} 23^{\prime} 15,87^{\prime \prime N}$ & SM & 20 & VI-VII & VII (Zone) & VII \\
\hline
\end{tabular}

Figure 7. Example of classified parametric list of the catalogued EEEs and earthquake archaeoseismological effects (EAEs) for the 16 selected earthquakes in the "full event files". The example, translated for this paper, contains macroseismic information for the first five sites of the AD 1863 Huércal-Overa earthquake (Intensity VIII). The full original list has 22 EEEs, 7 EAEs files and 13 complementary EMS data [10]. 


\begin{tabular}{|c|c|c|c|c|c|c|c|c|c|c|c|c|}
\hline $\begin{array}{l}\text { INFOF } \\
\text { HST } 1\end{array}$ & MACIC & I MAC & AL - & $A R$ & & & & & & & \multicolumn{2}{|c|}{$\begin{array}{c}\text { EFECTOS } \\
\text { GEOLÓGICOS }\end{array}$} \\
\hline EVENTO & $\begin{array}{l}\text { HORAY } \\
\text { MIN. }\end{array}$ & LONGITUD & LATITUD & $\begin{array}{c}\text { MAG } \\
\left(\mathrm{Mw} / \mathrm{Ms} / \mathrm{M}^{\star}\right)\end{array}$ & $\begin{array}{c}\text { EMS } \\
98\end{array}$ & $\begin{array}{c}\text { MSK } \\
64\end{array}$ & $\begin{array}{l}\text { ESI } \\
07\end{array}$ & $Q_{e}$ & $Q_{i}$ & $Q_{g}$ & \multicolumn{2}{|c|}{ LOCALIZACION TERREMOTO } \\
\hline HST 18630610 AD & 11:10 & $1956^{\prime} 0$ & $37^{\circ} 22^{\prime} \mathrm{N}$ & $4,2-4,6 \mathrm{M}^{*}$ & VI-VII & VII & VIII & B & B & A & \multicolumn{2}{|c|}{ Huércal-Overa. AL. } \\
\hline Tipo de Efectos & gados & $\Omega^{3 x}$ & 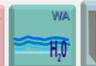 & ${ }_{\mathrm{H}, \mathrm{O}}^{\mathrm{HD}}$ & & & & & & & $\begin{array}{l}\text { Número de } \\
\text { Fichas } 29\end{array}$ & $\begin{array}{l}22 \text { EEEs } \\
07 \text { EAEs }\end{array}$ \\
\hline
\end{tabular}

Imagen Google Earth de la localización de efectos catalogados en la zona epicentral

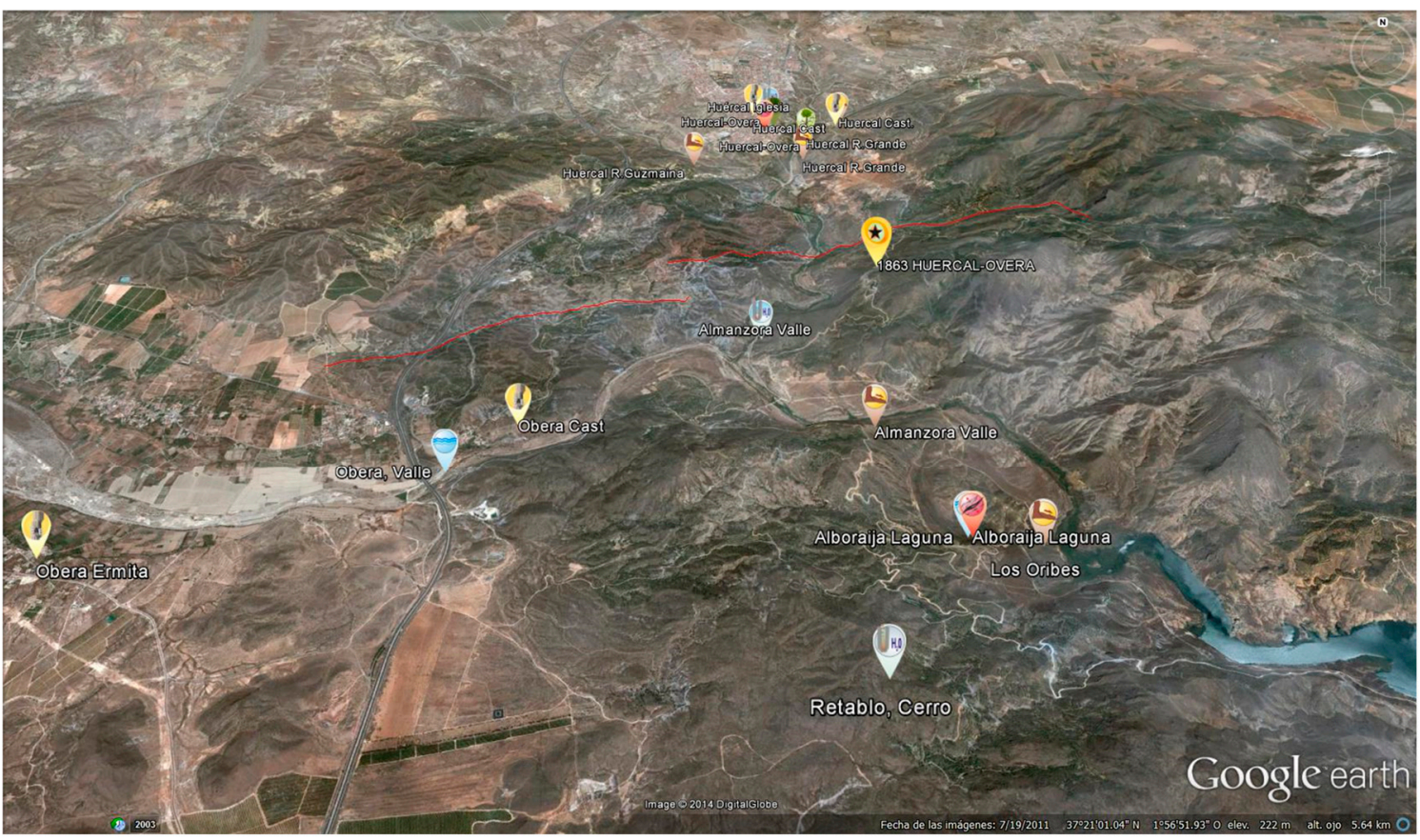

Figure 8. Example of Google Earth image extracted from the $\mathrm{kmz}$ file produced for each of the 16 selected earthquakes with "full event files". The example displays information for the macroseismic area of the AD 1863 Huércal-Overa earthquake [10].

The intensity maps, implemented in shaded-relief models of the affected areas, illustrate the intensity distribution in relation to the Quaternary active faults of the zone and the set of catalogued EEEs for each event (Figure 9). The style of the intensity maps tries to resemble the color-scales used in the instrumental seismicity maps of the USGS Earthquake hazard program (https://earthquake. usgs.gov/) [47]. As mentioned, the hybrid intensity maps incorporate all the EMS information (when available) coming from previous catalogues [7]. The EMS information is also provided at the end of the parametric list illustrated in Figure 7.

In the intensity maps EEEs localities are identified with circles of the same color of the corresponding intensity level (Figure 9). In many cases, the localities have "satellite data-points" represented by smaller colored circles representing other EEEs or EAEs around the stronger (or more important) one that occurred in that locality. The use of "satellite data-points" is based on the recommendations of the International Atomic Energy Agency (IAEA) on the guidelines of paleoseismic analyses to seismic hazard assessments in site evaluation for nuclear installations [48]. The identification and delineation of the geometry of intensity zones was done taking into account the location of the more important Quaternary faults of the region (black lines), but also the geology and geomorphology of the affected areas. In particular, the distribution of poorly consolidated Quaternary deposits and the different topographic contexts on which the documented EEEs occurred was key for the production of intensity maps. As illustrated in Figure 9, colored triangles identify complementary EMS data for different intensity levels. EMS data are especially important for a more accurate definition of the geometry for intensity zones VI to IV in the lower limit of sensitivity of the ESI-07 scale [5]. The intensity maps are not 
available for ancient or paleoseismic events only documented in one archaeological site of fault-trench excavation. In these cases the intensity maps are substituted by another type of graphic information from geoarchaeological or pure geological sources, such as a maps and sketches of oriented damage (ancient events) or the log of the fault-trench documenting the earthquake (paleoseismic events).

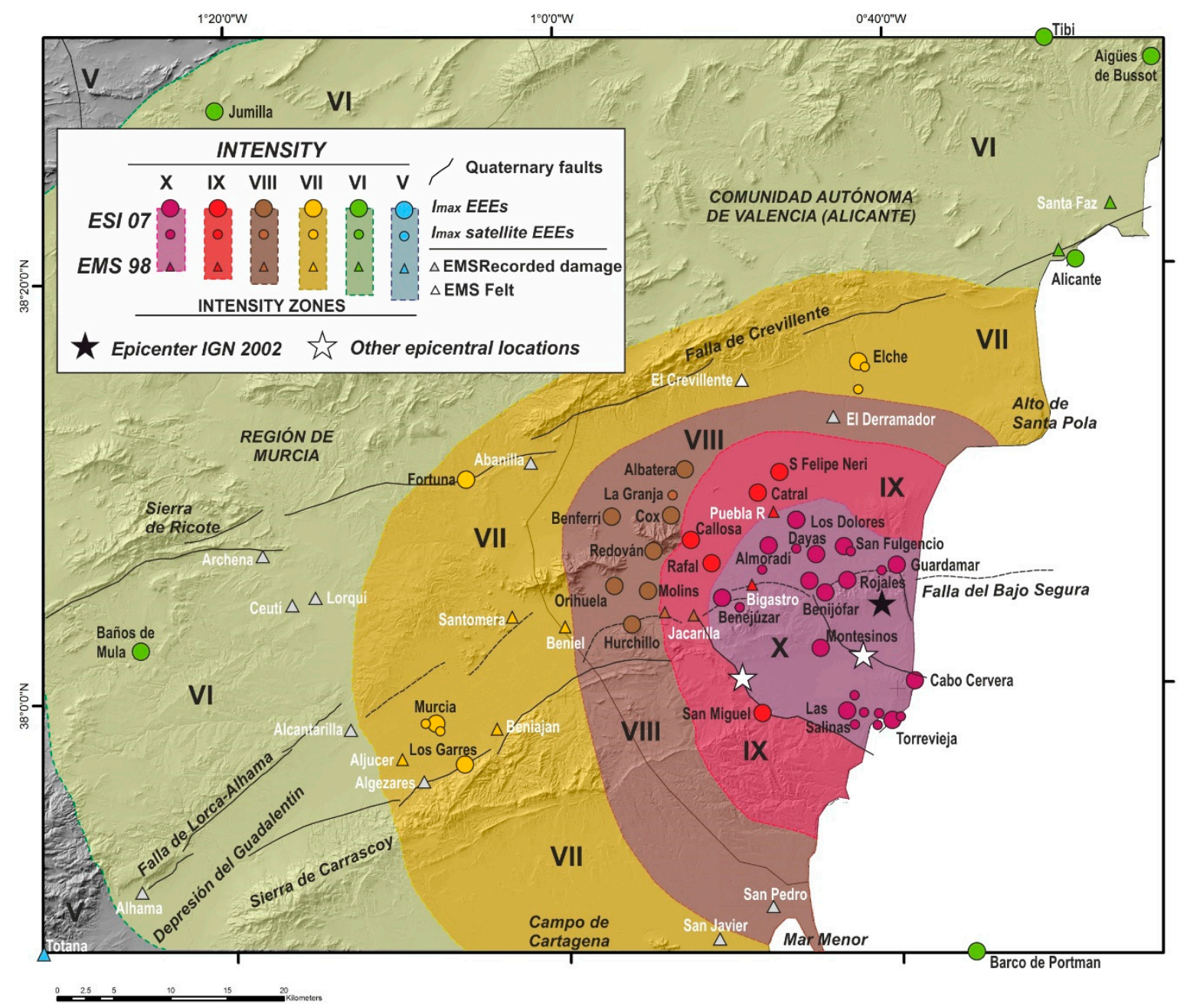

Figure 9. Example of hybrid ESI-EMS intensity map produced for the 16 selected earthquakes with "full event files" of the Spanish ESI-07 catalogue [10]. The example corresponds to the AD 1829 Torrevieja earthquake in Alicante (Intensity X).

For the best-documented cases the production of seismic scenarios (ShakeMaps) has been possible in terms of the peak ground acceleration (PGA: \%g) deduced from the intensity maps. These ShakeMaps have been produced following a similar methodology to that used by the USGS ShakeMap Programm [47], but specifically adapted to the Iberian Peninsula by Silva et al. [19]. The elaborated seismic scenarios are based on the implementation of "Ground Motion Prediction Equations" (GMPE) on detailed digital terrain models (5m/pixel DTMs) pixel by pixel. The selected pixel size $(5 \mathrm{~m})$ is clearly sufficient to identify individual EEEs and to upload detailed slope and geological data into the resulting shake models. This pixel size upgrades the $900 \mathrm{~m} /$ pixel DTMs used in the USGS earthquake hazard program [47] and allows one to define the contribution of topography (slope) and geology (loose soils) to the triggered environmental damage [19]. The selected GMPE for the production of seismic scenarios in the Spanish catalogue corresponds to those used in the first versions of the USGS Earthquake Hazard Program [49]. These equations are first generation GMPE, specifically designed for geodynamic contexts dominated by strike-slip faults in the SW EEUU [49], 
which in turn are similar to the geodynamic framework of southern Spain (Betic Cordillera; Figure 1), where the main strong earthquakes of the catalogue are placed [19].

These GMPE offer broad seismic scenarios in the range of the expected uncertainties for the hypothetical seismic source characterization of the historic, ancient and paleoseismic events analyzed in the catalogue. On the other hand, these basic first generation GMPE allow to implement simple source parameters (i.e. source location, fault type, fault dimensions/geometry and earthquake magnitude) in relation to epicentral distance (Joyner-Boore radius) [49], deduced Vs30 values from proxy data [50] and topographic and geologic correction factors specifically produced for Spain [19]. The modelling of seismic scenarios (shakemaps) for Spain is based on the large set of instrumental, macroseismic and geological data resulting from the last important earthquake that occurred in Spain (2011 Lorca Earthquake; 5.1 Mw; VIII ESI-07), which was used as a check-model in a ArcGis environment [19]. The Figure 10 illustrates the updated shakemap developed for the AD 1755 Lisbon earthquake-tsunami included in the catalogue.

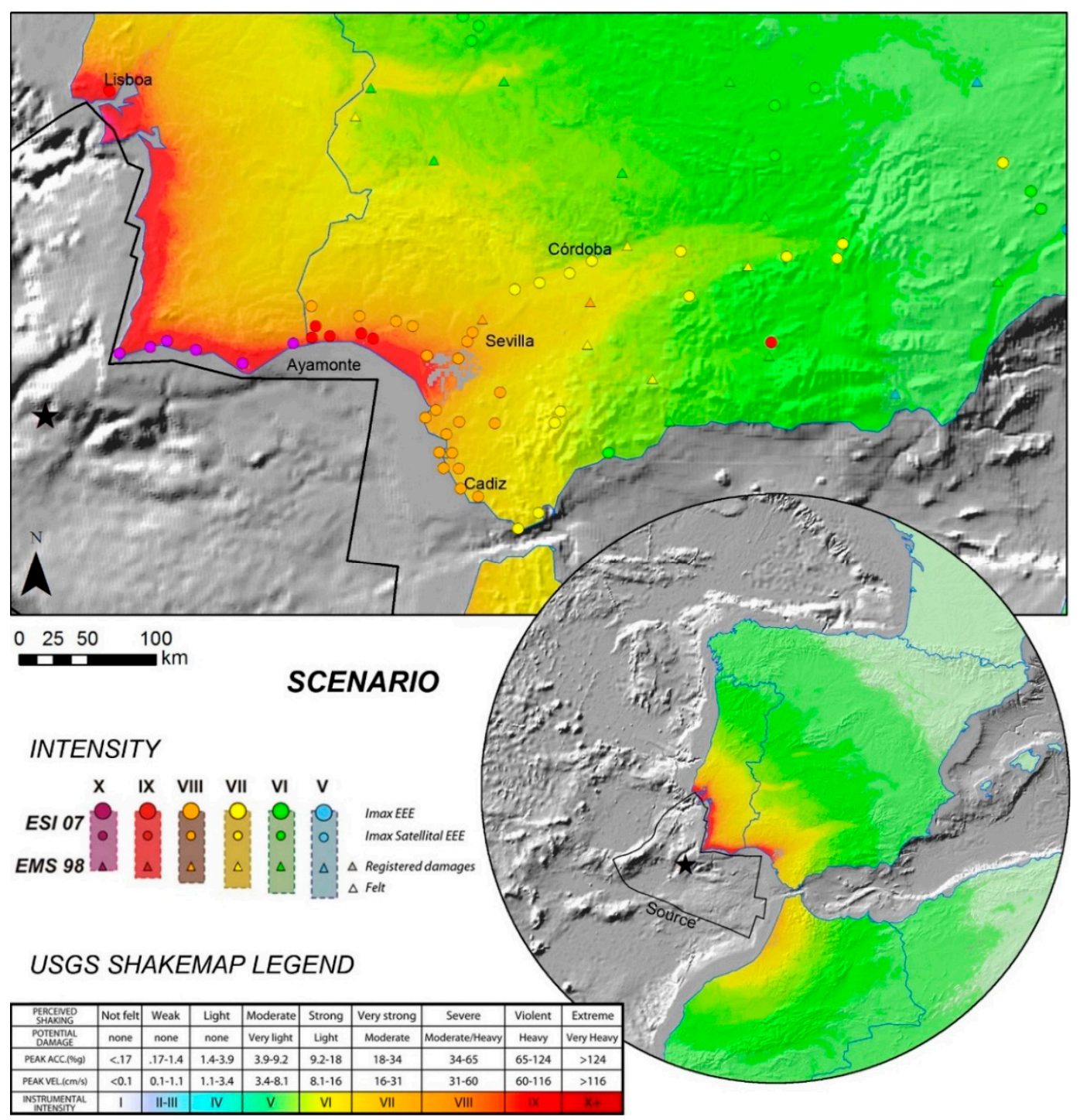

Figure 10. Example of seismic scenario (Shakemap) developed for the AD 1755 Lisbon earthquake and tsunami (XI ESI-07)—one of the 16 selected earthquakes with "full event files" of the Spanish ESI-07 catalogue [10]. The example corresponds to the AD 1755 Lisbon earthquake-tsunami (XI ESI-07). Note the dimensions of the seismogenic source as proposed by Silva et al. [17]. 


\subsection{Summary on the Structure and Content of the "Full Event Files"}

The information contained in the "full event files" is summarized in the following items:

- Event file (51 earthquakes): These files contain parametric data, earthquake type, quality indexes, summarized information on building (EMS-based) and environmental damage (ESI-based), a list of identified EEEs for the different categories of ESI-07 effects, and archaeoseismic damage (EAEs). Additionally, these files display summarized information on the geological data supporting the earthquake, a geological sketch of the Iberian Peninsula for location (Figure 2), five to six key references documenting the earthquake and a list of the authors compiling the information. Fifty one-page files in Spanish and English (Figure 5).

- Earthquake description in the Galbis Catalogue (16 selected Earthquakes): Transcription of original descriptions and references in these initial seismic catalogues. For those events not listed in the Galbis catalogue this section is substituted by a "general information" section including data from field, technical, scientific reports and scientific publications available for those earthquakes. Sixteen one-page sections.

- Earthquake environmental effects (16 selected earthquakes): Analysis and discussion of the catalogued EEEs in the format of a two-page short paper.

- Earthquake archaeological effects (16 selected earthquakes): Analysis and discussion of the catalogued EAEs in the format of a two-page short paper. In modern earthquakes, the analysis of EAEs is focused on its impact on the cultural heritage of the affected area. As in the previous case, this section has also a two-page format.

- Parametric list of the particular EEEs and EAEs (16 selected earthquakes), identified for each earthquake. For those cases with a great number of effects (above 50) the number of published EEEs/EAEs files was normalized to about 50 representative files (Figure 7).

- Parametric list of EMS data available for each earthquake (16 selected earthquakes) coming from the existing official databases of the IGN $[7,23]$.

- EEE and EAE files (totaling 322) for the 16 selected earthquakes, with detailed information in the geological and geomorphological context, ground conditions, as well as descriptions, interpretation and quantification of the particular EEE or EAE catalogued effect.

- Google Earth image (16 selected earthquakes) representative of the distribution of EEEs and EAEs coming from the $\mathrm{kmz}$ files produced for the catalogue which will be implemented in the near future in an online public database of the Geological Survey of Spain (Figure 8).

- ESI-07/EMS-98 hybrid intensity maps (16 selected earthquakes) on shaded relief models, specifically designed for the published catalogue. In the case of earthquakes with few intensity data, like ancient or paleoseismic events, the intensity map is substituted by damage maps/sketches or by the log of the fault-trench documenting the event (Figure 9).

- Seismic Scenarios or ShakeMaps (16 selected earthquakes) in terms of PGA values, based on those developed by the USGS ShakeMap Program but specifically adapted for the Iberian Peninsula (Figure 10).

- Reference list (16 selected earthquakes): Complete bibliographic list with the old historic documents and modern research papers documenting or analyzing the catalogued earthquake.

\subsection{Special "Full Event File" for the AD 1755 Lisbon Earthquake-Tsunami Event}

Due to the special features and size and large area affected for this earthquake its full event file contains additional information. This file has different independent sections on the analysis of tsunami effects, geological effects extracted from the examination of the about 1300 individual locality-reports for this earthquake kept in the Spanish Historical National Archives (Archivo Histórico Nacional; AHN) [51], from which 673 localities reported natural effects [17]. This file also has a section on the large set of far-field hydrological and hydrogeological anomalous effects reported for the northern area of the Iberian Peninsula, British islands, Europe, Africa, the Caribbean Sea and the oceanic islands of Canary, 
Madeira and Azores. Though most of the far-field effects are related to the tsunami propagation, some of them occurred in inland water bodies at Reading, Sussex, Plymouth, London (England); Lake district (Cumbria); Lakes Lomod and Ness (Scotland); Lake Binnenalster of Hamburg (Germany); Lakes Léman, Neuchatel and Zürichsee (Switzerland); Telpice Baths (Prague) and the Dal River in Sweden (Baltic Sea). Some of these last effects occurred more than 2000-3000 km away from the epicenter. This event has a total of 753 catalogued EEEs, 673 of them occurring in Spain [10].

All the above mentioned far-field natural effects were compiled in the volume 69 of the "Philosophical transactions of the Royal Society of London" published in December 1755 and reprinted in 1809 [52]. This volume contains an special section entitled: "An Extraordinary and Surprising Agitation of the Waters though without any perceptible Motion of the Earth having been observed in various parts of this Island, both Maritime and Inland, on the same Day and chiefly about the Time that the more Violent Commotion of both Earth and Waters so extensively affected many very distant Parts of the Globe" (pages 646 to 656). This special section collects 17 letters describing tsunami effects in littoral zones of the Atlantic Ocean, but also other 12 letters on the anomalous effects observed in inland water bodies at different parts of Europe. These very far-field effects represent an anomaly in relation to recent strong earthquake-tsunami events of similar size (i.e., 2004 Sumatra, 2010 Chile, 2011 Japan), which did not cause that variety of far-field anomalous effects [17,30].

The Lisbon event also has a particular section regarding other effects not truly considered by the ESI-07 scale [52], but of interest for this particular earthquake [10,51]. Long period waves on standing waters were recorded at 29 localities several hundreds of kilometers away in the whole of Spain, mostly in Central Castilla, but also in Cataluña (1200 km away) where the earthquake was not felt. Perception of an underground noise occurred almost simultaneously to ground shacking in 285 locations covering the whole of mainland Spain, except the north and northeast zones. Perception of ground waving and anomalous tree shaking was observed in many localities throughout the Guadalquivir valley. Finally, luminous effects observed in the sky ( 51 records) $5-4$ hours before the earthquake along the western sector of the Iberian Peninsula throughout a SW-NE band $600 \mathrm{~km}$ long (Huelva to Palencia) which have been also catalogued. These effects are interpreted as the occurrence of a comet or meteor crossing the sky [51], eventually exploding over the north of the Duero river basin (north Spain) with a great luminosity and a strong noise [10]. All the far-field EEEs, tree shaking and luminous effects were catalogued totaling 753 effects, but only 49 of them have individual "EEE files" in the recently published catalogue [10]. Taking into account the abovementioned other effects not considered in the ESI-07 (long period waves, underground noise, ground waving, etc.) the total number of effects would amount to over 1000 EEEs for the AD 1755 Lisbon event, which would deserve a separate analysis and catalogue.

\section{Brief Numerical Analysis of the Catalogued EEEs}

This section introduces a short analysis of the catalogued events for the 51 analyzed earthquakes for the maximum intensity of the events (Figure 11) and for the different intensity levels (Figure 12). As observed in the bar-diagram of Figure 11, the AD 1755 Lisbon event produced a large variety of effects in the entire range of intensity levels, even where the earthquake was not felt. The most conspicuous reported effects were those related to hydrological (HA), hydrogeological (HD) or anomalous waves in inland water bodies (WA), which were more frequent and widely observed for intensities IV to VII (Figure 11). Noticeable ground effects were also liquefaction (LQ), ground cracks (GK) and slope movements (SM) for intensities VI to IX and strong tsunami damage from intensity VIII (Figure 11). Due to the offshore nature of the event, primary effects were few and mostly related to cases of subsidence of the coastal area around the Gulf of Cádiz. 


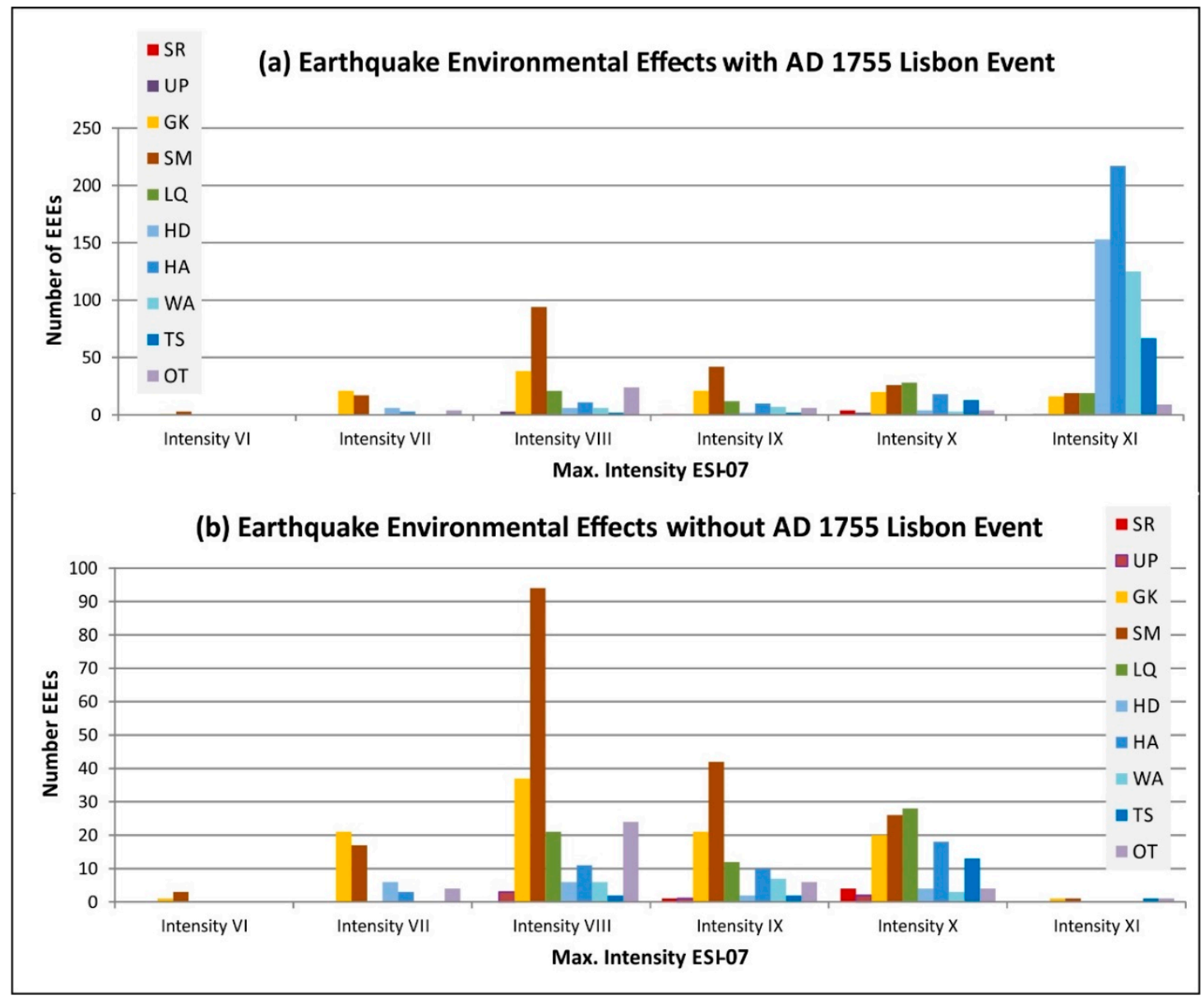

Figure 11. Statistical analysis of EEEs that occurred in the 51 catalogued events considering the maximum intensity $\left(I_{\max }\right)$ of the triggering event: (a) Distribution of EEEs for different intensity earthquakes considering the complete analyzed earthquake list; (b) distribution of EEEs for different intensity earthquakes removing the data for the AD 1755 Lisbon event.

The Figure 11 illustrates the distribution of triggered EEEs listed in the "event files" for the whole number of catalogued earthquakes by their maximum intensity. The analyzed data total 976 EEEs including those of the AD 1755 (Figure 11a) but are only 489 without the mentioned event (Figure 11b). The different distribution of EEEs is also noticeable when considering or not the Lisbon Event, which displaces the statistical mode to intensity XI due to the large number of hydrological effects (HA, HD and WA) reported for this earthquake (Figure 11a). On the contrary, removing the Lisbon EEEs, the statistical mode is clearly located in intensity VIII, where the most frequent effects are slope movements (SM), ground cracks (GK) and ground liquefaction (LQ) with an amount of 204 EEEs (Figure 11b), which practically doubles the number of EEEs for intensities IX and X (around 100 each). This is a statistical bias because intensity VIII events are the most numerous among the catalogued Spanish events (Tables 1 and 2). In any case, it seems clear that the minimum $I_{\max }$ value to produce secondary earthquake effects with a relative long-lasting geological record is intensity VII. 


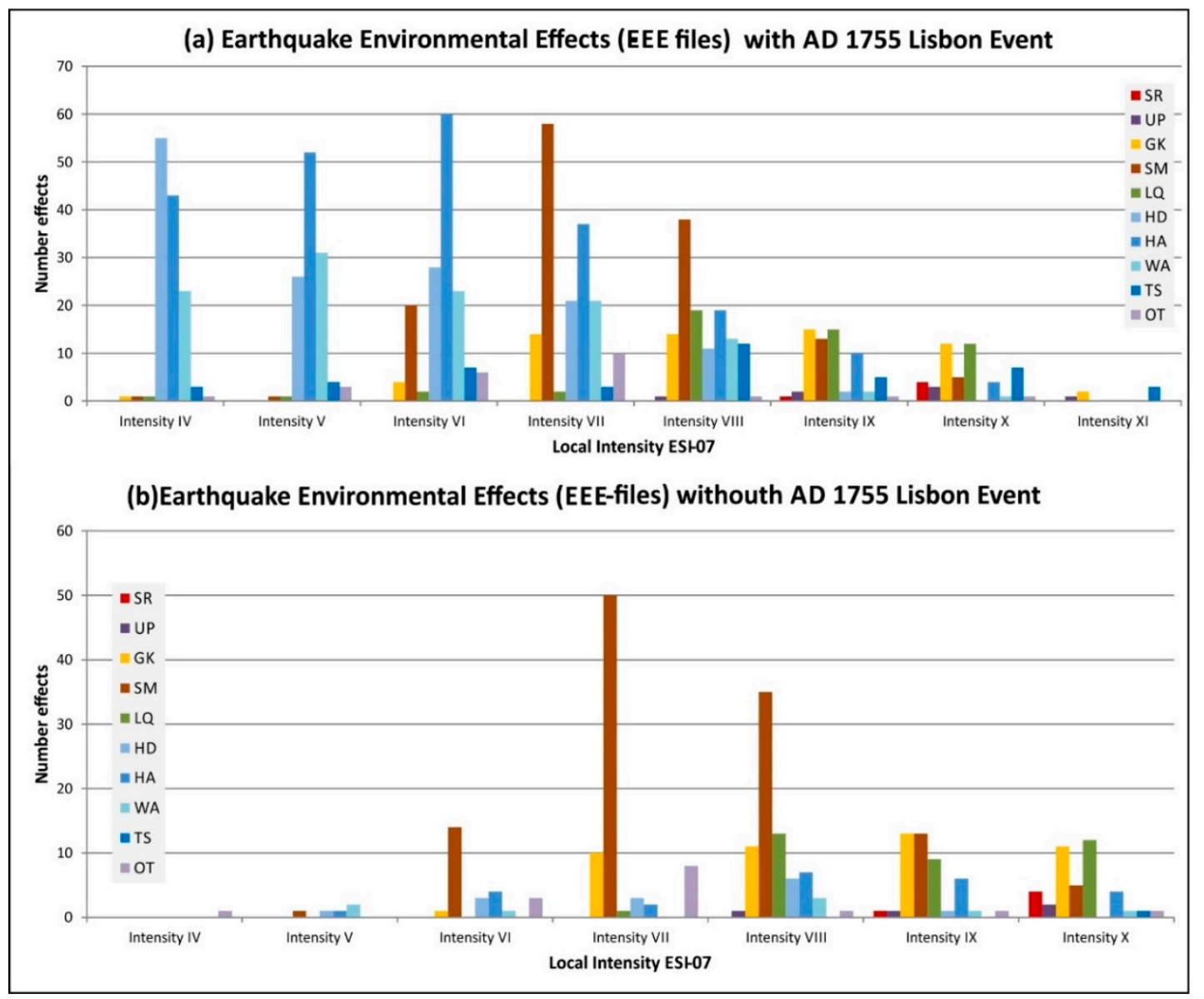

Figure 12. Statistical analysis of EEEs occurred in the 16 selected earthquakes with full event files considering the local intensity for the sixteen analyzed events. (a) Distribution of EEEs for different intensity zones considering the sixteen analyzed earthquakes; (b) distribution of EEEs for different intensity zones removing the data for the AD 1755 Lisbon event.

Figure 12 displays the catalogued EEEs by their intensity level, but only for the 16 selected earthquakes with "full event files", which sum up to a total of 811 records. Again, the comparison of the diagrams with and without the AD 1755 Lisbon event offers a very different distribution of the number and type of catalogued EEEs. Once the large amount of hydrological and tsunami effects produced by the Lisbon event are removed, again intensities VII and VIII collect the largest number of ground effects (SM, GK and LIQ) (Figure 12b). In many cases, the catalogued ground cracks are related to lateral spreading linked to ground liquefaction or to slope movements. This last category of ESI-07 effects is the more abundant one in the analyzed earthquakes, but the SM peak for intensity VII in Figure 12 is again a statistical bias due to the large amount of slope movements catalogued for the 2011 Lorca earthquake (Figure 12b). It is also noticeable that primary effects start to be observable for intensity VIII, but the few cases of surface ruptures occur for events of intensity $\geq \operatorname{IX}$ (Figure 12b). This is the general case for inland Spain, where surface faulting events are very rare, but the occurrence of extensive secondary earthquake effects is common. These mainly include hazardous slope movements, ground liquefaction and ground cracking processes in inland events, but also damaging tsunamis in the Gulf of Cádiz (Atlantic Ocean) and Alborán Sea (Mediterranean Sea) around the Gibraltar strait (Figure 2). In fact, the strongest earthquakes occurred within the Iberian Peninsula have moderate magnitudes around 6.0-7.0 Mw $[7,19,23]$ but they triggered strong intensity levels up to IX-X as a consequence of the participation of geological effects in environmental and building damage. This is of special interest for the dangerous earthquake-tsunami events around the Gibraltar strait zone. In this sense, Figures 11 and 12 display the number of catalogued EEEs with and without the data corresponding to the 1755 
Lisbon earthquake-tsunami. In both cases, the noise introduced by this special "Atlantic Event" is clear in relation to the EEEs commonly triggered by the strongest earthquakes that occurred within the Iberian Peninsula.

\section{Achievements and Future Perspectives}

In spite of the existence of databases with information on earthquake environmental effects-like that developed by the Italian Geological Survey (ISPRA), which includes data on about 200 globally distributed earthquakes (http://193.206.192.211/wfd/eee_catalog/viewer.php) [53], or databases with paleoseismic and active faults information [2] —none of them proceed to a proper ESI-07-based classification and interpretation. In this way, as noted by Serva [2] after the devastating 2011 Japan earthquake-tsunami (Tohoku) the IAEA recommended to the members states to carefully consider secondary earthquake ground effects in order to envisage a more accurate definition of the seismic hazard (in terms of intensity) in zones with nuclear installations [47] and the ESI-07 scale was largely considered in the published recommendations [54]. Some very recent catalogues and on-line databases, like that developed by the "Italian National Geophysics and Volcanologic Survey (INGV)" [55], consider ground effects, but they are treated in a descriptive-informative way and are not used for true intensity assessments following the ESI-07 guidelines. As a consequence, currently there is no similar catalogue like that recently published in Spain [10] considering geological and archaeoseismological data extending the earthquake records to the recent geological past. However, the growing data on earthquake environmental effects, and complementary archaeoseismological analyses, will improve our knowledge on the seismic history of a region in the future, by the recovering of lost earthquakes from the geological record. The future of SHA studies needs in a mandatory way the incorporation of geological and archaeoseismological data to offer to the modern societies more comprehensive data within the temporal range (recurrence periods) of the seismic cycle. In this sense, the Spanish catalogue incorporates seismic scenarios for historical events (i.e., Figure 10) which will help to develop a better definition of the seismic hazard for forthcoming SHA studies but also for the preparation of future earthquake drills [20].

Author Contributions: Project design, management, conceptualization, coordination and funding acquisition, investigation on historical earthquakes, supervision of all Event and EEE files and writing-original draft preparation, P.G.S; project management, administration, and funding acquisition, investigation on paleoseismic and ancient events, supervision and final edition, M.A.R.P.; design of graphic information-software for intensity maps and visualization, investigation on ancient events and cultural heritage, writing-review and editing, J.L.G.R.; design of graphic information-software for seismic scenarios, management of information in ArcGis environment and writing - review and editing, J.E.V.; investigation of historical and ancient events, geochronologic databases, writing - review and editing, R.P.L.; database management, statistical analyses, supervision review and editing of all the Event and EEE files, M.B.B.D.

Funding: This research was funded by the Spanish Research Project MINECO-FEDER CGL2015-67169-P (QTECSPAIN-USAL). This is contribution of the QTECT-AEQUA Working Group.

Acknowledgments: The authors are grateful to the rest of the geologists and scientists contributing to the publication of the $2^{\text {nd }}$ Edition of the Catalogue of the geological effects of earthquakes in Spain: Teresa Bardají (UAH), Pedro Huerta (USAL), M. Ángeles Perucha (IGME), Francisco García-Tortosa (UJAEN), Javier Lario (UNED), Pedro Vicente Gómez (USAL) and Elvira Roquero (UPM).

Conflicts of Interest: The authors declare no conflict of interest.

\section{References}

1. Serva, L.; Vittori, E.; Comerci, V.; Esposito, E.; Guerrieri, L.; Michetti, A.M.; Mohammadioun, B.; Mohammadioun, G.C.; Porfido, S.; Tatevossian, R. Earthquake Hazard and the Environmental Seismic Intensity (ESI) Scale. Pure App. Geophys. 2016, 173, 1479-1555. [CrossRef]

2. Serva, L. History of the Environmental Seismic Intensity Scale ESI-07. Geosciences 2019, 9, 210. [CrossRef]

3. Michetti, A.M.; Esposito, E.; Guerrieri, L.; Porfido, S.; Serva, L.; Tatevossian, R.; Vittori, E.; Audemard, F.; Azuma, T.; Clague, J.; et al. Intensity Scale ESI 2007; ISPRA: Roma, Italy, 2007; Volume 74, ISBN 9788824029032. 
4. Grünthal, G. European Macroseismic Scale 1998: EMS98; Musée Natioal d’Historie Narurelle: Luxembourg, 1988 ; p. 99.

5. Silva, P.G.; Guerrieri, L.; Michetti, A.M. Intensity scale ESI 2007 for assessing earthquake intensities. In Encyclopedia of Earthquake Engineering; Beer, M., Kougioumtzoglou, I.A., Patelli, E., Au, S.K., Eds.; Springer: Berlin/Heidelberg, Germany, 2015; ISBN 978-3-642-35344-4.

6. IAEA. Seismic Hazards in Site Evaluation for Nuclear Installations; IAEA Safety Standards Series No. SSG-9; International Atomic Energy Agency: Vienna, Austria, 2010; p. 193.

7. Martínez Solares, J.M.; Mezcua, J. Catálogo Sísmico de la Península Ibérica (880 a.C.-1900); Instituto Geográfico Nacional: Madrid, Spain, 2002; p. 253. (In Spanish)

8. Udías, A. Historical Earthquakes (before 1755) of the Iberian Peninsula in Early Catalogs. Seism. Res. Let. 2015, 86, 999-1003. [CrossRef]

9. Silva, P.G.; Rodríguez-Pascua, M.A.; Giner-Robles, J.L.; Pérez-López, R.; Lario, J.; Perucha, M.A.; Bardají, T.; Huerta, P.; Roquero, E.; Bautista Davila, M.B. Catálogo de los Efectos Geológicos de los Terremotos de España, $1^{a}$ Ed; Riesgos Geológicos y Geotecnia 4. IGME: Madrid, Spain, 2014; p. 352. (In Spanish)

10. Silva, P.G.; Rodríguez-Pascua, M.A.; Giner-Robles, J.L.; Pérez-López, R.E.; García-Tortosa, F.J.; Gómez Vicente, P.; Bardají, T.; Perucha, M.A.; Huerta, P.; Lario, J.J.; et al. Catálogo de los Efectos Geológicos de los Terremotos de España, $2^{a}$ Ed. Revisada y Ampliada; Riesgos Geológicos y Geotecnia 6. IGME: Madrid, Spain, 2019; p. 804. (In Spanish)

11. IGN. Actualización de Mapas de Peligrosidad Sísmica en España 2012; Instituto Geográfico Nacional (IGN): Madrid, Spain, 2013; p. 228. (In Spanish)

12. Silva, P.G.; Rodríguez-Pascua, M.A.; Pérez-López, R.; Bardají, T.; Lario, J.; Alfaro, P.; Martínez-Díaz, J.J.; Reicherter, K.; Giménez García, J.; Giner, J. Catalogación de los efectos geológicos y ambientales de los terremotos en España en la Escala ESI 2007 y su aplicación a los estudios paleosismológicos. Geotemas 2008, 6, 1063-1066. (In Spanish)

13. Rodríguez-Pascua, M.A.; Pérez-López, R.; Silva, P.G.; Giner-Robles, J.L.; Garduño-Monroy, V.H.; Reicherter, K. A Comprehensive Classification of Earthquake Archaeological Effects (EAE) for Archaeoseismology. Quat. Int. 2011, 242, 20-30.

14. Bradley, R.; García Sanjuán, L. Sudden time? Natural disasters as a stimulus to monument building, from Silbury Hill (Great Britain) to Antequera (Spain). In The Neolithic of Europe; Bickle, P., Cummings, V., Hoffman, D., Pollard, J., Eds.; Oxbow Books: Oxford, UK, 2017; pp. 188-200.

15. Ferrater, M.; Silva, P.G.; Ortuño, M.; Rodríguez-Pascua, M.A.; Masana, E. Archaeoseismologic analysis of a Late Bronze Age site on the Alhama de Murcia Fault: Tira del Lienzo (Murcia, SE Spain). Geoarchaeology 2015, 30, 151-165. [CrossRef]

16. Silva, P.G.; Pérez-López, R.; Rodríguez-Pascua, M.A.; Roquero, E.; Giner Robles, J.L.; Huerta, P.; Martínez-Graña, A.; Bardají, T. Macroseismic analysis of slope movements triggered by the 2011 lorca earthquake (Mw 5.1): Application of the ESI-07 scale. Geogaceta 2015, 57, 35-38.

17. Silva, P.G.; Elez, J.; Giner-Robles, J.L.; Gómez-Diego, P.V.; Rodríguez-Pascua, M.A.; Roquero, E.; Martínez-Graña, A.; Bardají, T. The AD 1755 Lisbon Earthquake-Tsunami: Modeling the seismic source from the analysis of environmental and building macroseismic data. GNS Sci. Misc. Ser. 2017, 110, 358-361.

18. Duarte, J.C.; Rosas, F.M.; Terrinha, P.; Schellart, W.P.; Boutelier, D.; Gutscher, M.-A.; Ribeiro, A. Are subduction zones invading the Atlantic? Evidence from the southwest Iberia margin. Geology 2013, 41, 839-842. [CrossRef]

19. Silva, P.G.; Elez, J.; Giner-Robles, J.L.; Rodríguez-Pascua, M.A.; Pérez-López, R.; Roquero, E.; Bardají, T.; Martínez-Graña, A.M. ESI-07 ShakeMaps for instrumental and historical events in the Betic Cordillera (SE Spain): An approach based on geological data and applied to seismic hazard. Quat. Int. 2017, 451, 185-208. [CrossRef]

20. Pérez-López, R.; Elez, J.; Silva, P.G.; Giner-Robles, J.L.; Rodríguez-Pascua, M.A.; Roquero, E.; Bardají, T. Utilización de shakemaps y efectos geológicos como escenarios para simulacros en gestión de desastres. In Proceedings of the $3^{\text {a }}$ Reunión Ibérica sobre Fallas Activas y Paleosismología IBERFAULT III, Alicante, Spain, 11-15 June 2018. (In Spanish).

21. Martínez Solares, J.M. Sismicidad pre-instrumental: Los grandes terremotos históricos en España. Enseñ. Cienc. Tierra 2011, 19, 296-304. (In Spanish)

22. IGME. Informe Geológico Preliminar del Terremoto de Lorca del 11 de Mayo de 2011 (Mw 5,1); Instituto Geológico y Minero de España (IGME): Madrid, España, 2011; p. 47. (In Spanish) 
23. IGN. Official web page of the Spanish Seismic Network; Red Sísmica Nacional. Instituto Geográfico Nacional (IGN): Madrid, España. Available online: http://www.ign.es/web/ign/portal/sis-catalogo-terremotos (accessed on 26 July 2019). (In Spanish)

24. Silva, P.G.; Borja, F.; Zazo, C.; Goy, J.L.; Bardají, T.; De Luque, L.; Lario, J.; Dabrio, C.J. Archaeoseismic record at the ancient Roman City of Baelo Claudia (Cádiz, South Spain). Tectonophysics 2005, 408, 129-146. [CrossRef]

25. Rodríguez-Pascua, M.A.; Silva, P.G.; Perucha, M.A.; Giner-Robles, J.L.; Heras, C.; Bastida, A.B.; Carrasco García, P.; Roquero, E.; Bardají, T.; Lario, J.; et al. Seismically induced liquefaction structures in La Magdalena archaeological site, the 4th century AD Roman Complutum (Madrid, Spain). Sediment. Geol. 2016, 344, 34-46. [CrossRef]

26. Rodríguez-Pascua, M.A.; Silva, P.G.; Garduño-Monroy, V.H.; Pérez-López, R.; Israde-Alcántara, I.; Giner-Robles, J.L.; Bischoff, J.; Calvo, J.P. Ancient earthquakes from archaeoseismic evidence during the Visigothic and Islamic periods in the archaeological site of "Tolmo de Minateda" (SE of Spain). In Special Paper of the Geological Society of America; Sintubin, M., Stewart, I., Niemi, T., Altunel, E., Eds.; Geological Society of America: Boulder, CO, USA, 2010; Volume 471, pp. 171-184.

27. Grützner, C.; Ruano, P.; Jabaloy, A.; Galindo-Zaldívar, J.; Becker-Heidmann, P.; Sanz de Galdeano, C.; Rudersdorf, A.; Reicherter, K. Late Holocene rupture history of the Ventas de Zafarraya Fault (Southern Spain). Cuatern. Geomorfol. 2013, 27, 51-61.

28. Rodríguez-Vidal, J.; Ruiz, F.; Cáceres, L.M.; Abad, M.; González-Regalado, M.L.; Pozo, M.; Carretero, M.I.; Monge-Soares, A.M.; Gómez-Toscano, F. Geomarkers of the 218-209 BC Atlantic tsunami in the Roman Lacus Ligustinus (SW Spain): A palaeogeographical approach. Quat. Int. 2011, 242, 201-212. [CrossRef]

29. Gràcia, E.; Vizcaino, A.; Escutia, C.; Asioli, A.; Rodés, A.; Pallás, R.; García-Orellana, J.; Lebreiro, S.; Goldfinger, C. Holocene earthquake record offshore Portugal (SW Iberia): Testing turbidite palaeoseismology in a slow-convergence margin. Quat. Sci. Rev. 2010, 29, 1156-1172. [CrossRef]

30. Lario, J.; Zazo, C.; Goy, J.L.; Silva, P.G.; Bardají, T.; Cabero, A.; Dabrio, C.J. Holocene palaeotsunami catalogue of SW Iberia. Quat. Int. 2011, 242, 196-200. [CrossRef]

31. Silva, P.G.; Bardají, T.; Roquero, E.; Martínez-Graña, A.; Perucha, M.A.; Lario, J.; Giner Robles, J.L.; Rodríguez-Pascua, M.A.; Pérez-López, R.; Cabero, A.; et al. Seismic palaeogeography of coastal zones in the Iberian Peninsula: Understanding ancient and historic earthquakes in Spain. Cuatern. Geomorfol. 2015, 29, 31-56.

32. Gómez, F.; Arruda, A.M.; Rodríguez-Vidal, J.; Cáceres, L.M.; Ruiz, F. Eventos marinos de alta energía y cambios traumáticos en los asentamientos costeros del Suroeste de la Península Ibérica. Cuatern. Geomorfol. 2015, 29, 57-74. (In Spanish) [CrossRef]

33. Ambraseys, N. Earthquakes in the Eastern Mediterranean and the Middle East: A Multidisciplinary Study of Seismicity up to 1900; Cambridge University Press: New York, NY, USA, 2009; p. 901.

34. Rodríguez-Pascua, M.A.; Silva, P.G.; Giner-Robles, J.L.; Pérez López, R.; Perucha, M.A.; Martín-González, F. Arqueosismología: una nueva herramienta para la sismología y la protección del patrimonio. Rev. Otarq 2016, 1, 151-169. (In Spanish) [CrossRef]

35. Rodríguez-Pascua, M.A.; Giner-Robles, J.L.; Silva, P.G.; Pérez-López, R.; Perucha, M.A.; Elez, J.; Bardají, T.; Roquero, E.; Sánchez Ramos, I.; Morín de Pablos, J. The record of ancient and historic earthquakes in the archaeological site of Idanha a Vela (Central Portugal; Iberian Peninsula). GNS Sci. Misc. Ser. 2017, 110, 338-341.

36. Giner-Robles, J.L.; Bardají, T.; Rodríguez-Pascua, M.A.; Silva, P.G.; Roquero, E.; Elez, J.; Perucha, M.A.; Baena, R.; Guerrero, I.; Fernández-Caro, J.J.; et al. Análisis arqueosismológico del conjunto arqueológico romano de Mulva- Munigua (Sevilla, España). Geotemas 2016, 16, 605-608. (In Spanish)

37. Arteaga, C.; García Menárguez, A.; Prados Martínez, F.; Baudot, E. El Cabezo del Estaño de Guardamar (Alicante, España): Avance Preliminar de Evidencias Arqueosísmicas en un asentamiento Fenicio del Siglo VII a.C. Rev. Mundo Investig. 2016, 2, 146-155. (In Spanish)

38. Giner-Robles, J.L.; Rodríguez-Pascua, M.A.; Silva, P.G.; Pérez-López, R. Efectos sísmicos en yacimientos arqueológicos: catalogación y cuantificación arqueosismológica. Bol. Geol. Min. 2018, 129, 445-463. (In Spanish) [CrossRef]

39. Lario, J.; Bardají, T.; Silva, P.G.; Zazo, C.; Goy, J.L. Improving the coastal record of tsunamis in the ESI-07 Scale: Tsunami Environmental Effects Scale (TEE-16 scale). Geol. Acta. 2016, 14, 179-193. 
40. Rodríguez-Pascua, M.A.; Silva, P.G.; Giner-Robles, J.L.; Perucha, M.A.; Roquero, E.; Bardají, T.; Elez, J.; Pérez-López, R. Using earthquake archaeological effects for the identification of seismic damage and intensity assessments in the cultural heritage. In Scientific Management of Cultural Heritage; Pechioli, L., D'Amico, S., Venuti, V., Eds.; Springer Handbooks: Berlin, Germany, 2019; in press.

41. Mezcua, J.; Rueda, J.; García Blanco, R.M. Iberian Peninsula Historical Seismicity Revisited: An Intensity Data Bank. Seism. Res. Let. 2013, 84, 9-18. [CrossRef]

42. Mezcua, J.; Martínez Solares, J.M. Sismicidad del área Ibero-Mogrebí; Instituto Geográfico Nacional (IGN). Publicación 203: Madrid, Spain, 1985; p. 301. (In Spanish)

43. Wells, D.L.; Coppersmith, K.J. New empirical relationships among magnitude, rupture length, rupture width, rupture area, and surface displacement. Bull. Seism. Soc. Am. 1994, 84, 974-1002.

44. Silva, P.G.; Giner-Robles, J.L.; Reicherter, K.; Rodríguez-Pascua, M.A.; Grüztner, C.; García-Jiménez, I.; Carrasco, P.; Bardají, T.; Santos, G.; Roquero, E.; et al. Los terremotos antiguos del conjunto arqueológico romano de Baelo Claudia (Cádiz, Sur de España): Quince años de investigación arqueosismológica. Estud. Geol. 2016, 72, e050. [CrossRef]

45. Galbis, J. Catálogo Sísmico de la zona Comprendida Entre los Meridianos $5^{\circ}$ E y $20^{\circ} \mathrm{W}$ de Greenwich y los Paralelos $45^{\circ}$ y $25^{\circ}$ Norte; Instituto Geográfico Nacional: Madrid, Spain, 1932 \& 1940; Volumes I and II. (In Spanish)

46. NCSE-02. Real Decreto 997/2002, de 27 de septiembre. Boletín Oficial del Estado (BOE). Norma de la Construcción Sismorresistente Española 2002, 244, 35898-35967. (In Spanish)

47. Wald, D.J.; Worden, B.C.; Quitoriano, V.; Pankow, K.L. ShakeMap Manual: Technical Manual, User's Guide, and Software Guide; U.S. Geological Survey: Boulder, CO, USA, 2005; p. 132.

48. IAEA. The Contribution of Paleoseismology to Seismic Hazard Assessment in Site Evaluation for Nuclear Installations, TEC-DOC 1767; International Atomic Energy Agency: Vienna, Austria, 2015; p. 206.

49. Boore, D.M.; Joyner, W.; Fumal, T. Equations for estimating horizontal response spectra and peak acceleration from Western North American earthquakes: a Summary of recent Work. Seismol. Res. Lett. 1997, 68, 128-153. [CrossRef]

50. Wald, D.J.; Allen, T.I. Topographic slope as a proxy for seismic site conditions and amplification. Bull. Seismol. Soc. Am. 2007, 97, 1379-1395. [CrossRef]

51. Martínez Solares, J.M. Los Efectos en España del Terremoto de Lisboa; Monografías IGN, 19. IGN: Madrid, Spain, 2001; p. 756. (In Spanish)

52. Hutton, C.; Shaw, G.; Pearson, R. Philosophical Transactions of the Royal Society of London 1750-1755; London: London, UK, 1809; Volume LXIX (69), pp. 646-656.

53. Guerrieri, L. The EEE Catalogue: A global catalogue of Earthquake Environmental Effects. Quat. Int. 2012, 279, 179-180. [CrossRef]

54. Audemard, F.; Azuma, T.; Baiocco, F.; Baize, S.; Blumetti, A.M.; Brustia, E.; Clague, J.; Comerci, V.; Esposito, E.; Guerrieri, L.; et al. Earthquake Environmental Effects for Seismic Hazard Assessment: The ESI Intensity Scale and the EEE Catalogue; ISPRA: Rome, Italy, 2015; Volume 97, ISBN 978-88-9311-007-5.

55. Guidoboni, E.; Ferrari, G.; Tarabusi, G.; Sgattoni, G.; Comastri, A.; Mariotti, D.; Ciuccarelli, C.; Bianchi, M.G.; Valensise, G. CFTI5Med, the new release of the catalogue of strong earthquakes in Italy and in the Mediterranean area. Sci. Data 2019, 6, 1-15. [CrossRef]

(C) 2019 by the authors. Licensee MDPI, Basel, Switzerland. This article is an open access article distributed under the terms and conditions of the Creative Commons Attribution (CC BY) license (http://creativecommons.org/licenses/by/4.0/). 